\title{
The Determinants of IPO-Related Shareholder Litigation: The Role of CEO Equity Incentives and Corporate Governance
}

\author{
Xingli Li
}

\section{A Thesis}

In

The John Molson School of Business

\author{
Presented in Partial Fulfillment of the Requirements \\ for the Degree of Master of Science in Administration (Finance) at \\ Concordia University \\ Montreal, Quebec, Canada
}

March 2010

(C) Xingli Li 2010 
Library and Archives

Canada

Published Heritage

Branch

395 Wellington Street Ottawa ON K1A ON4

Canada
Bibliotheque et

Archives Canada

Direction du

Patrimoine de l'édition

395 , rue Wellington

Ottawa ON K1A ON4

Canada
Your file Votre référence

ISBN: 978-0-494-67275-4

Our file Notre refférence

ISBN: $978-0-494-67275-4$
NOTICE:

The author has granted a nonexclusive license allowing Library and Archives Canada to reproduce, publish, archive, preserve, conserve, communicate to the public by telecommunication or on the Internet, loan, distribute and sell theses worldwide, for commercial or noncommercial purposes, in microform, paper, electronic and/or any other formats.

The author retains copyright ownership and moral rights in this thesis. Neither the thesis nor substantial extracts from it may be printed or otherwise reproduced without the author's permission.
AVIS:

L'auteur a accordé une licence non exclusive permettant à la Bibliothèque et Archives Canada de reproduire, publier, archiver, sauvegarder, conserver, transmettre au public par télécommunication ou par l'Internet, prêter, distribuer et vendre des thèses partout dans le monde, à des fins commerciales ou autres, sur support microforme, papier, électronique et/ou autres formats.

L'auteur conserve la propriété du droit d'auteur et des droits moraux qui protège cette thèse. Ni la thèse ni des extraits substantiels de celle-ci ne doivent être imprimés ou autrement reproduits sans son autorisation.
In compliance with the Canadian Privacy Act some supporting forms may have been removed from this thesis.

While these forms may be included in the document page count, their removal does not represent any loss of content from the thesis.
Conformément à la loi canadienne sur la protection de la vie privée, quelques formulaires secondaires ont été enlevés de cette thèse.

Bien que ces formulaires aient inclus dans la pagination, il n'y aura aucun contenu manquant. 


\begin{abstract}
The Determinants of IPO-Related Shareholder Litigation:

The Role of CEO Equity Incentives and Corporate Governance
\end{abstract} Xingli Li

This paper empirically examines whether CEO equity incentives as well as other corporate governance mechanisms are related to the incidence of shareholder litigation. Our study differs from previous studies, which have largely focused on seasoned firms, by examining how CEO incentives at a firm's pre-IPO stage affect the incidence of IPOrelated shareholder litigation. We examine a sample of 81 U.S. IPO firms (issued between 1997 and 2007) that are sued under Section 11 of the 1933 Securities Act within 3 years of their IPO and an industry-size-year matched sample of 81 control firms. We have assembled a novel, hand-collected data set that measures the lawsuit, corporate governance, and firm characteristics of these 162 firms. We report a significant positive association between the likelihood of securities fraud allegations and CEO equity incentives, which is consistent with the idea that there is a "dark side" to executive equity incentives. This association is robust to alternative model specifications, sample selection criteria, and estimation methods. In addition, we find that the risk of being sued is higher for firms whose board is dominated by insiders, whose CEOs are older, have a shorter tenure, or who founded the firm. 


\section{ACKNOWLEDGEMENTS}

I would like to express the deepest appreciation to my supervisor Dr. Thomas Walker. Without his persistent guidance, help and encouragement, this thesis would not have been possible. The input and time of the carrying committee members, Dr. Harjeet S. Bhabra and Dr. Yaxuan Qi, are also appreciated.

I am also grateful to Dr. Kuntara Pukthuanthong at San Diego State University for her guidance and valuable comments relating to this research.

At last but not least, I would like to dedicate my work to my beloved parents, Zhenhua $\mathrm{Li}$ and Jie Liu, who were always there for me and supported me all the way. Special thanks also go to Dena Meng, who accompanied me during the toughest time of completing the thesis. 


\section{TABLE OF CONTENTS}

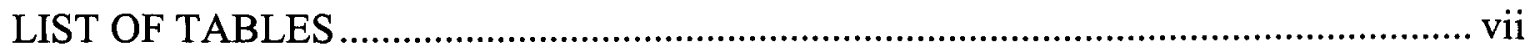

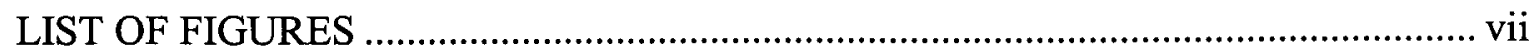

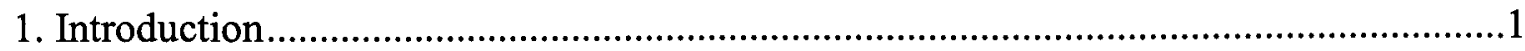

2. Concepts of executive pay and shareholder litigation ..........................................5

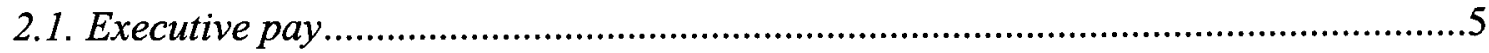

2.2. Shareholder litigation ...........................................................................

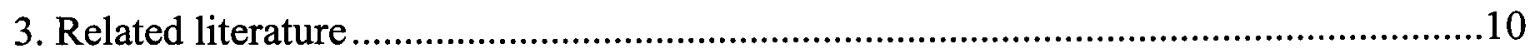

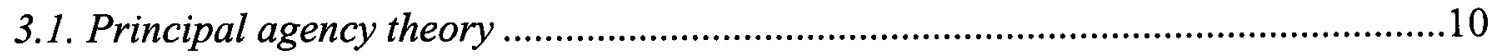

3.2. Equity incentives and earnings management .................................................12

3.3. Equity incentives and earnings restatements ..............................................15

3.4. Equity incentives and accounting fraud ........................................................16

3.5. Equity incentives and private securities litigations..........................................18

4. Underlying theory and hypothesis development................................................19

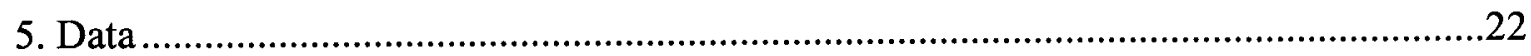

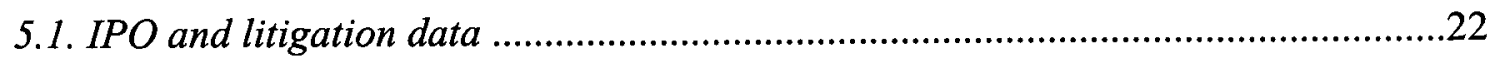

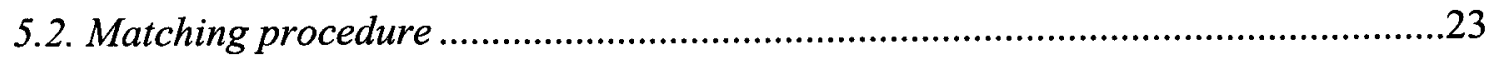

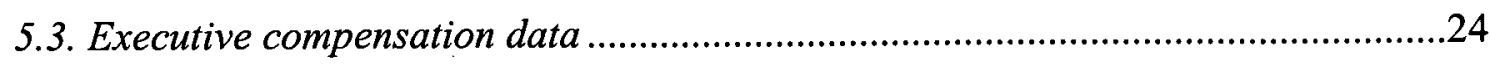

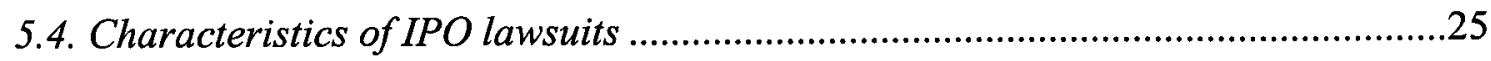

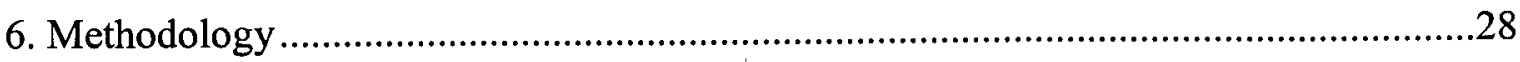

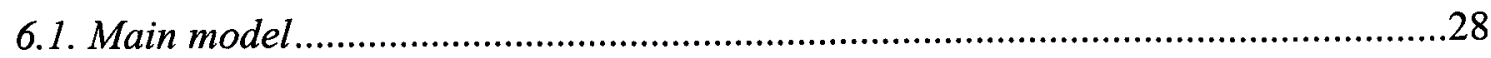

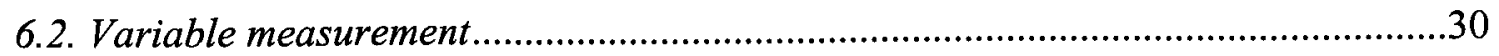


6.2.1. Executive compensation and equity ownership variables ........................... 30

6.2.2. Control variables .................................................................................. 32

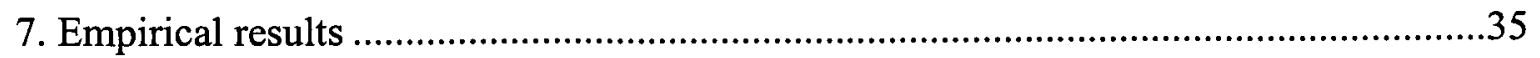

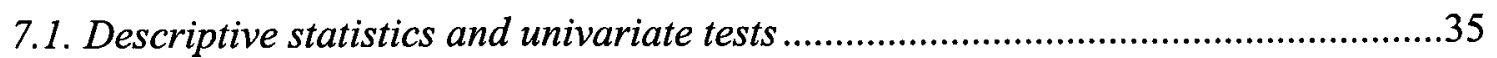

7.2. Regression results (with normal equity incentives) ..........................................37

7.3. Regression results (with abnormal equity incentives) ........................................4 41

7.4. Regression results high tech firms $v$ s. non-high tech firms ................................41

7.5. Regression results non-accounting related fraud vs. accounting related fraud .....43

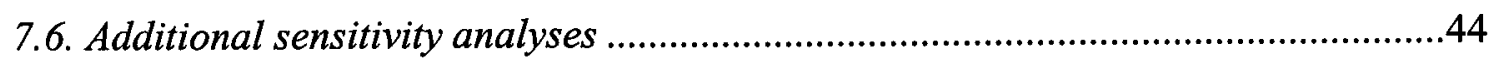

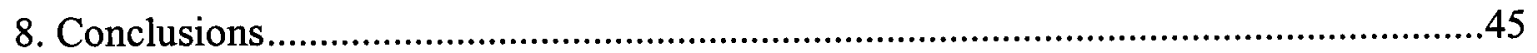

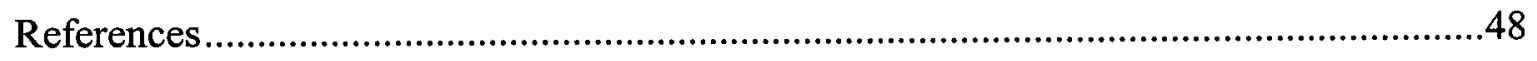

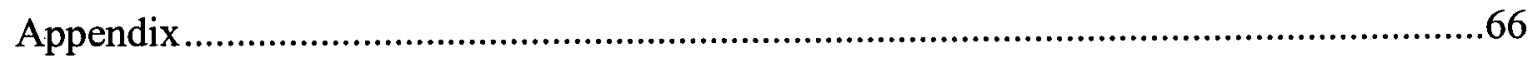




\section{LIST OF TABLES}

Table 1: Sample distribution across years and industries ............................................... 53

Table 2: Nature, resolution, and timing of lawsuits......................................................... 55

Table 3: Characteristics of sued vs. non-sued firms ........................................................5

Table 4: Conditional matched-pair logistic regression ...................................................... 59

Table 5: Conditional matched-pair logistic regression (abnormal incentives) .................. 61

Table 6: Conditional matched-pair logistic regression

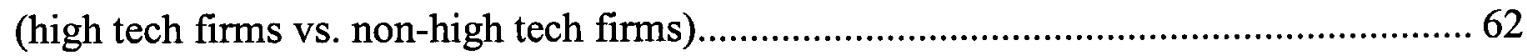

Table 7: Conditional matched-pair logistic regression

(accounting related litigation vs. non-accounting related litigation) ................................6 63

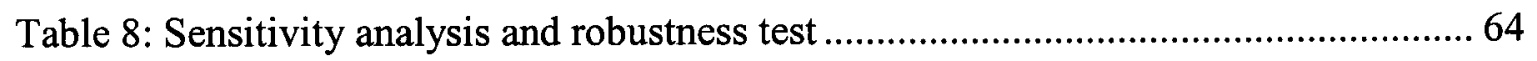

\section{LIST OF FIGURES}

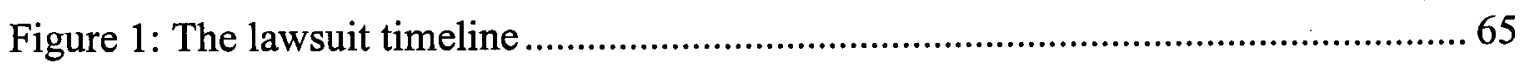




\section{Introduction}

Principal-agent theory, beginning with Jensen and Meckling (1976), suggests that stock-based executive compensation and equity holdings help reduce agency conflicts by aligning the interests of corporate managers with those of a firm's shareholders. Yet, despite its allure and widespread use, stock-based compensation has come under increased scrutiny since the early 2000 s by being tied to numerous corporate scandals at such firms as MCI WorldCom, Enron, and HealthSouth that involved earnings manipulation and various other violations of the securities laws. In many of these cases, managers hyped up their firm's share price through accounting fraud as well as misrepresentations and omissions of adverse developments, only to exercise their options and sell their stock holdings at elevated levels before revealing their firm's true financial position.

Our study attempts to contrast the expected positive effects of equity-based incentives with their disadvantages. Recent studies examine the unintended consequences of equity-based incentives including earnings management (Ke, 2001; Gao and Shrieves, 2002; Cheng and Warfield, 2005; Bergstresser and Philippon, 2006), accounting restatements (Burns and Kedia, 2006; Efendi et al., 2007; Harris and Bromiley, 2007; Baber et al., 2009), accounting fraud (Erickson et al., 2006; Johnson et al., 2009), and class action lawsuits (Denis et al., 2006; Peng and Roell, 2008). To the best of our knowledge, all prior studies that have related accounting irregularities and legal actions to CEO incentives have focused on seasoned firms, while the relationship remains unexplored for IPO firms. We aim to close this gap in the literature by providing the first 
study that examines the relation between the incidence of IPO-related class action lawsuits and CEO equity incentives including incentives from pre-IPO options (defined as options that are issued prior to an IPO and whose exercise price is not directly linked to the offer price), and from pre-IPO equity ownership controlling for a variety of variables that are related to IPO litigation risk. Pukthuanthong, Roll and Walker (2007) suggest that IPO firms provide an ideal setting for studying executive managerial compensation and firm performance. In the same vein, we believe that IPO firms present us with a particularly fertile laboratory for studying how CEO incentives affect a firm's likelihood to be sued for securities fraud in connection with their IPO. First, IPO firms differ significantly from seasoned firms. As Bhabra and Pettway (2003) note, "Information contained in a prospectus is often the first window to a potential investor about the firm's past and its projected future performance" (Bhabra and Pettway, 2003, pg. 370). Therefore, the level of information asymmetry tends to be higher for IPO firms which, in turn, may give top executives a better opportunity to deceive the market. Second, founders or professional managers who decide to take their firm public are likely to confront a variety of new pressures that they haven't experienced before. On one hand, they have to fulfill the often high expectations of underwriters, analysts, venture capitalists, and outsiders. On the other hand, they are likely to experience a substantial shift in their personal wealth functions as their compensation moves away from being salary- and bonus-based to being closely tied to the firm's share price. These factors may drive some top executives to portray their firms in an overly positive light and engage in manipulative or fraudulent activities during the IPO process in order to meet outside expectations or maximize their own wealth. Third, the use of IPO-related class action 
lawsuits is particularly appealing because these lawsuits tend to be defined more narrowly (typically alleging misrepresentation or omissions in a firm's IPO prospectus) than lawsuits against seasoned firms, which are typically much more diverse in nature. Lastly, from the perspective of IPO investors, pursuing an IPO firm in court tends to be less costly than pursuing a seasoned firm as lawsuits brought under Section 11 of the 1933 Act do not require them to prove that they relied on false or misleading information or omissions in the offering statement.

In this paper, by examining IPO related class action lawsuits, we shed some light on the question: Do firms in which CEOs have higher equity incentives face a higher risk of class action lawsuits? As we use class action lawsuits as a proxy for executives committing fraud, our findings should be particularly interesting to IPO investors who are concerned about the potential loss they may encounter due to fraudulent information provided in the prospectus that will boost up the offer price and may affect the future performance of their IPO shares.

We analyze a sample of 81 U.S. IPO firms that went public between 1997 and 2007 and subsequently become the target of a shareholder class action lawsuit under Section 11 of the 1933 Securities Act and an industry-size-year matched control sample of 81 non-sued IPO firms. We assemble a unique, hand-collected data set that contains detailed information on the lawsuit characteristics, executive compensation and equity ownership structure, and other corporate governance characteristics of these 162 firms. Our findings support our main hypothesis that firms in which CEOs have more equity incentives prior to the IPO are more likely to become the target of a securities class action 
after the IPO. This result is robust when we consider abnormal equity incentives, i.e. equity incentives beyond the desired level. However, the positive association only prevails in high tech firms and becomes insignificant when we focus our attention on non-tech firms. When classifying lawsuits based on their alleged fraud allegations (i.e. accounting-related cases vs. non-accounting cases), our results are similar in both subsamples. In addition, we find evidence that IPO firms whose board is dominated by insiders face a higher litigation risk. Consistent with Agrawal and Chadha (2005) and Agrawal and Cooper (2009), but in contrast to Efendi et al. (2007), we do not find a significant relationship between the incidence of litigation and the combination of the CEO and chairmanship roles in a given firm. Finally, we find several CEO traits to be related to the incidence of litigation. Specifically, firms with older CEOs, CEOs who have a shorter tenure, or CEOs who also founded the firm are more likely to be sued in connection with their IPO.

The remainder of this paper is organized as follows. Section 2 reviews some basic concepts pertaining to executive pay and shareholder litigation. Section 3 discusses the related literature. Section 4 presents the underlying theory and hypotheses. Section 5 describes the data selection process and characteristics of IPO lawsuits. Section 6 details the methodology used in this study. Section 7 provides the descriptive statistics and univariate tests and reports results for our multivariate models. The final section offers concluding remarks and gives suggestions for future research in this area. 


\section{Concepts of executive pay and shareholder litigation}

\subsection{Executive pay}

Executive compensation determines how top level managers of business corporations are paid. The institutional aspect is that the board of directors is responsible for designing compensation. ${ }^{1}$ Although pay practices are different across firms and industries, executive pay packages typically include one or more of the following five components: grants of stock, grants of long-term incentive plans (including restricted stock plans and multi-year accounting-based performance plans), grants of restricted stock, grants of stock options or stock appreciation rights (SAR), ${ }^{2}$ and cash compensation (salary, bonuses, and other cash compensation) (Murphy, 1999; Ronen and Yaari, 2008).

Companies may offer shares to their top executives and employees (stock grants) to align their interests with those of the company's shareholders. The original entrepreneurs or top executives already own some of the companies' stocks prior to the IPO. However, they typically commit not to sell their personal holdings during a lockup period that commonly lasts 90 to 180 days and in some cases even longer after the IPO. Besides regular stock grants (usually called unrestricted stock grants (Balsam, 2002)), stock grants can be restricted. An example of a restriction imposed upon a stock grant might be that shares cannot be sold for a certain time period that usually lasts three or

\footnotetext{
${ }^{1}$ Although boards of directors make all major decisions related to executive compensation, initial recommendations for pay levels and new incentive plans are typically suggested by the company's human resource department. These recommendations are usually sent to top executives for approval and revision before they are passed on to the full board of directors for approval (Murphy, 1999).

${ }^{2}$ Stock appreciation rights (SARs) typically reward employees or executives with cash payments based on the increase in the value of a specified number of shares over a defined period of time. Similar to options, employees or executives have flexibility in when to choose to exercise the SAR when they are in the money. In contrast to options, employees or executives do not need to purchase and then sell the shares to receive the profit. Instead, the corporation pays them, in cash or common stock, the excess of the current market price of the shares over the aggregate exercise price (Balsam, 2002).
} 
four years (Cheng and Warfield, 2005) or before the firm reaches a specific performance goal.

Executive stock options are contracts that provide executives the right to buy a fixed number of shares at a specified exercise price during a pre-specified time period. Typically, these stock options cannot be exercised immediately. Murphy (1999) reports that the usual time span between the granting date and the exercise date is at least three years and seldom more than five years (a typical restriction written in the prospectus is that 25 percent of options issued are allowed to be vested in each of the four years following the original granting date). In addition, if employees or executives leave the company before exercising or vesting, the options are typically forfeited. When options become exercisable or vested, managers can either hold exercisable options or exercise the options and hold shares instead.

The two major components of cash compensation include an executive's base salary and bonuses. The base salary is a minimum fixed payment the manager receives irrespective of the performance of the company during a given year. This provides management some level of insurance with respect to the minimum base compensation they can expect to receive. A bonus, on the other hand, is only received by managers when they or the firm achieve a certain performance target. Annual bonuses or contracts that provide incremental cash compensation on top of this base salary are a significant part of executive compensation (Holthausen et al., 1995). As survey data by Hay Management Consultants (1991) shows, $91 \%$ of all publicly traded U.S. firms have some type of annual bonus plans for senior-level executives. In addition, Hay (1991) finds that 
at least $80 \%$ of the CEO bonus is related to corporate financial performance. While earnings are the most popular performance measure for annual bonus plans, ROI (return on invested capital) is also broadly used. ${ }^{4}$

Executive pay in corporations has undisputedly increased in the last few decades, while worker's pay has stagnated (Hengartner, 2006). The compensation of top executives increased by 6.8 percent per year from 1980 to 2003 (Frydman and Saks, 2007). Hengartner (2006) reports that the average real pay for chief executive officers of S\&P 500 firms grew from U.S. \$3.5 million in 1992 to U.S. \$14.7 million in 2000. In recent years, average real CEO pay constitutes around $8 \%$ of corporate profits for U.S. firms (Balsam, 2002, pg. 262).

Suffering from the sub-prime financial crisis, chief executives at the largest U.S. corporations received less total compensation in 2008 than in 2007. Specifically, the average total compensation for CEOs dropped 6 percent from 11.07 million dollars in 2007 to 10.4 million dollars in 2008 (The American Federation of Labor and Congress of Industrial Organizations, 2008).

\subsection{Shareholder litigation ${ }^{5}$}

Firms that engage in fraudulent practices that mislead or deceive investors are liable to be sued. In the last century as well as in recent years, U.S. Congress has issued

\footnotetext{
${ }^{4}$ In practice, there may be exceptions under certain circumstances. During the recent financial crisis, for example, CEOs in the three largest banks that received money through the federal government's Troubled Asset Relief Program (TARP) remained on the list of 200 top-paid CEOs in 2008. In addition, only 39 of the 200 top-paid CEOs did not receive bonuses in 2008. (For details, see "Who Moved My Bonus? Executive Pay Makes a U-Turn," The New York Times, April 5, 2009).

${ }^{5}$ This section provides a general review of each act. For details on these rules and regulations, please refer to information provided by the Office of the Law Revision Counsel (http://uscode.house.gov).
} 
several laws that aim to protect investors from managers' fraudulent behavior in primary and secondary market transactions. There are four legal reforms that are often highlighted in the literature (DuCharme et al., 2004; Peng and Roell, 2008).

The Securities Act of 1933 is the first major congressional law to regulate the securities industry. It was enacted by Congress in the aftermath of the stock market crash of 1929 and during the subsequent Great Depression. The major objectives of this act are to make sure that investors receive significant information regarding securities offerings and to prohibit deceit, misrepresentation, and other fraud in the sale of securities. If IPO investors feel that they have made an investment decision based on misleading or false information disseminated by a company, they may sue the firm, the underwriter, or any person who signed the registration statement under Section 11 of the Securities Act of 1933 (Civil Liabilities on Account of False Registration Statement). In lawsuits brought under Section 11 of the 1933 Act, the plaintiffs (investors) are not required to prove that they relied on misleading or deceitful information in the offering registration statement. Rather, the burden of proof falls on the defendant firm.

The Securities Exchange Act of 1934 governs securities transactions in the secondary market and regulates exchanges and broker-dealers. As such, it is different from the Securities Act of 1933, which generally deals with primary market transactions. Usually, firms and their executives are sued under Section 10b of the Securities and Exchange Act of 1934 (Manipulative and Deceptive Devices) by investors who believe that they received false or misleading information or that the firm failed to disclose materially relevant information. Unlike under Section 11 of the 1933 Act, under Section 
10b-5 of the 1934 Act, investors must prove that the information they relied on was flawed, and that this reliance led to their loss. In other words, the cost of proof falls on the plaintiff(s). The Exchange Act has been amended several times towards the end of the $20^{\text {th }}$ century. One of the most important reforms is the Private Securities Litigation Reform Act (PSLRA) of 1995.

The Private Security Litigation Reform Act of 1995 (PSLRA) raised the pleading standards of Section 10b-5 of the Securities Exchange Act of 1934 to reduce the number of "frivolous" securities lawsuits filed in federal courts. The essence of this act is that investors cannot proceed with a case unless they can strongly prove the existence of deliberate fraud, compared with Section 10b-5 of the Securities and Exchange Act of 1934, under which a case could proceed with minimal evidence. It is difficult for plaintiffs to obtain such evidence to proceed with a case. ${ }^{6}$ Johnson et al. (2007) find evidence that the PSLRA was at least partially successful in discouraging frivolous securities lawsuits and that suits have become more merit-based since then. However, Choi (2007) finds that firms with smaller offerings or firms which engaged in fraud for which no hard evidence is publicly announced are less likely to face private securities class action litigation after the PSLRA. Based on this, he cautions that while the PSLRA lowered the incidence of frivolous litigation, it also blocks meritorious suits.

\footnotetext{
${ }^{6}$ See Bloomberg's Bloomberg official website (http://www.bloomberg.com/apps/news?pid=20601039\&refer=columnist_quinn\&sid=axkhffRnncpI) which notes that the PSLRA raised pleading standards in three specific ways: first, it imposed a requirement that false statements be pleaded "with particularity"; second, it required that pleading create a "strong inference" of scienter; and third, it demanded that plaintiffs prove loss causation. For more information, see also the Office of the Law Revision Counsel (http://uscode.house.gov).
} 
The Sarbanes-Oxley Act (SOX) was passed by Congress on July 30, 2002, after a number of major corporate and accounting scandals that involved high profile firms such as Enron, Tyco International, Adelphia, Peregrine Systems, and WorldCom. SOX was characterized by former president George W. Bush as including "the most far-reaching reforms of American business practices since the time of Franklin Delano Roosevelt." The legislation established enhanced standards for all U.S. public company boards, management and public accounting firms and aimed to reinforce corporate accountability and professional responsibility (SEC, 2002). Although it is not mandatory, any private firm may wish to comply with the SOX financial framework requirements during their preparation for an initial public offering (IPO).

\section{Related literature}

In this section, we briefly review the principal agency theory, both from a theoretical perspective and in terms of the related empirical evidence. Next, we review the literature regarding the unintended consequences of equity-based incentives including earnings management, accounting restatements, SEC Accounting and Auditing Enforcement Actions and private securities litigation.

\subsection{Principal agency theory}

Since the late 1970 s, agency theory has become one of the main theoretical foundations that underlying studies of executive compensation (Hengartner, 2006). In a corporation, outside shareholders who have no executive rights act as a principal to the insiders (agents) who are in charge of the company. Inside managers and outside shareholders can have divergent interests when managers only own a small percentage of 
the firm. Inside managers (agents) may seek to maximize their personal utility, which is not aligned with shareholder value maximization. Therefore, a substantial body of theoretical work, starting with Jensen and Meckling (1976), posits that agency problems can be mitigated and firm value maximization is achieved when the risk-neutral manager owns a large percentage of the firm. Following Jensen and Meckling's (1976) theoretical work, several papers have investigated the role of equity-based compensation in resolving agency problems. For example, Haugen and Senbet (1981) theoretically prove that the agency problem can be effectively solved through a strategy that prudently combines call and put options retained by the owner-managers and external financiers, respectively. Other studies also show empirical results consistent with the incentive alignment view (Brickley et al., 1985; Lewellen et al., 1985; Lambert and Larcker, 1987; Mehran, 1995). However, there are inconsistent results to the incentive alignment view under the formal agency framework. Jensen and Murphy (1990) find that, on average, an increase of shareholder wealth of 1,000 dollars is only associated with an increase of 3.25 dollars of total CEO wealth (including pay, options, stockholdings, and dismissal ${ }^{7}$ ) over the period 1974-1986, which leads them to conclude that CEO equity incentives are too weak to provide economically meaningful incentives. Yermack (1995) finds that agency theory cannot explain the patterns of CEO stock option awards using a sample of 792 U.S. public corporations between 1984 and 1991. Meulbroek (2001) questions the cost efficiency of executive stock options towards incentive alignment as they argue that undiversified managers will value their equity-based compensation less than their market value and this deadweight loss empirically can be quite large. More recent theoretical

\footnotetext{
${ }^{7}$ Managers who face poor performance are threatened by management dismissal, which therefore provides value-increasing incentives (Jensen and Murphy, 1990).
} 
studies including Goldman and Slezak (2006), Crocker and Slemrod (2007), and Peng and Roell (2008) consider two types of efforts by top managers in their models, which are (1) increasing the stock price by increasing future cash flows and (2) increasing the stock price by manipulating information.

Not surprisingly, given the discouraging evidence in support of the principal agent theory, recent empirical studies have increasingly focused on the link between executive incentives and their unintended or adverse consequences.

\subsection{Equity incentives and earnings management}

Equity-based holdings and compensation provide conflicting incentives to manage earnings. As pointed out by Ronen and Yaari (2008, pg. 84), inflating earnings appears to be optimal for short-horizon earnings management as the higher the market price, the higher the value of one's holdings. However, the inflated market price makes it difficult to earn a raise of compensation in the future. Therefore, long-horizon earnings management should focus on deflating earnings. In general, most of the recent literature supports the existence of earnings management that tends to be used to inflate earnings. ${ }^{8}$

Gao and Shrieves (2002) use fixed-effect ordinary least squares regressions to examine the relation between executive compensation and earnings management. Their study differs from previous studies as they examine earnings management from a comprehensive view of the compensation contract, rather than focusing on one or two

\footnotetext{
${ }^{8}$ Healy (1985) is the first researcher to suggest that managers may decrease current reported earnings so as to increase future compensation. Managers tend to select negative discretionary accruals to hoard reported earnings for future use when earnings before discretionary accruals either fall sufficiently far below the lower bound or above the upper bound specified in the bonus plan. However, subsequent researchers do not support Healy's (1985) argument about deflating earnings when the earnings are too low (see. For example, Holthausen, et al., 1995)
} 
particular items in the contract. They find that the size of current year stock options, previous year in-the-money options, the incentive intensity of current year stock options, and bonuses are positively related to the intensity of earnings management, as measured by the absolute value of current discretionary accruals scaled by assets. However, they only find weak support for a positive relationship between the incentive intensity of restricted stock and earnings management intensity. Bergstresser and Philippon (2006) do not examine the relationship between each item in the compensation package and earnings management; rather, they examine the association between CEO equity-based incentives and earnings management while controlling firm characteristics and firm industry classification. They find evidence that CEOs whose overall compensation is more sensitive to their company's share price are often associated with companies that show a higher level of earnings management. Cheng and Warfield (2005) find that managers with high equity incentives are more likely to report earnings that meet or just beat analysts' forecasts using stock-based compensation and stock ownership data over the 1993-2000 time period. Ke (2001) measures the upward and downward earnings management associated with executive compensation in the same context using a probit regression. He finds that the probability of reporting a small increase in earnings is associated with an increase in CEO equity-based compensation incentives and a decrease in a firm's book-to-market ratio.

There are only few studies that directly link managers' salary to the probability of earnings management. The main reason may be the fact that salary's sensitivity to price movement as a result of earnings management is zero during any given year. ${ }^{9}$ However,

\footnotetext{
${ }^{9}$ Some exception exists when salary is adjusted according to reported earnings (Gao and Shrieves, 2002).
} 
although salary is fixed within a given year, it changes between years according to the managers' performance. Murphy (1999) points out that risk-averse managers will naturally prefer a dollar increase in base salary to a dollar increase in target bonus or other compensation. Therefore, a high level of executive salary may lower the incentive of managers to manipulate earnings. Gao and Shrieves (2002) postulate a non-positive relationship between earnings management and the salary levles. Because of a "ratchet effect" ${ }^{\prime 10}$, Ronen and Yaari (2008, pg.77) hypothesize that a new CEO has an incentive to decrease income in the first year of his tenure. In addition, Gao and Shrieves (2002) find that the intensity of earnings management is negatively related to salary but positively related to bonuses.

Unlike salary, bonuses have received a lot of attention from academic researchers. Of particular interest in recent years has been the link between bonuses and earnings management. Healy (1985), one of the first academics who examined this topic, argues that managers are able to increase their payoffs by inflating reported earnings. However, they also have an incentive to deflate earnings when the economic earnings either already yield the maximum bonus (i.e. they are above the upper bound), or are too low (below the lower bound) for a manager to earn a bonus since they can save reported income by deflating earnings for future use. Some papers find support for Healy's hypothesis. For example, Guidry et al. (1999) use business unit-level data instead of firm-level data to reduce the aggregation problem arriving from firm level data and potential mixed effects

\footnotetext{
${ }^{10}$ Ratchet effect: A company's good performance in a given year is "punished" in the subsequent year because it is difficult for the company to achieve its target performance again in the future as the expected benchmark performance increases.
} 
of long-term performance and stock-based incentive compensation effects. They find that managers of business units in the "MID" portfolio make income-increasing discretionary accruals relative to those in the "UPP" and "LOW" portfolios. ${ }^{11}$ However, some studies, such as Gaver et al. (1995) and Holthausen et al. (1995) find no evidence that managers manipulate earnings downwards when they are below the lower bound necessary to receive any bonus. Rather, they find income smoothing, which suggests that when earnings are low, managers favor income-increasing behavior.

\subsection{Equity incentives and earnings restatements}

Not all earnings management is illegal or should be considered as corporate fraud. It is only when GAAP standards are violated that they are considered truly fraudulent earnings manipulations. To differentiate between the two, several studies consider the occurrence of earnings restatement to identify fraudulent firms. Burns and Kedia (2006) identify 215 firms that restated earnings due to accounting irregularities identified by the General Accounting Office (GAO) over the period 1995-2001. They find a positive relation between the likelihood of a restatement being made and stock option compensation but fail to find any significant association between other components of CEO compensation (equity holdings, restricted stock, long-term incentive payouts, and salary plus bonus) and the likelihood to restate.

Efendi et al. (2007) differ in their methodology from Burns and Kedia (2006) because not only do they use a binary logistic regression, but also they employ an ordered

\footnotetext{
${ }^{11}$ Guidry et al. (1999) construct three portfolios based on the relative size of bonuses paid to the firm's managers. Firms in the lower bound portfolio (LOW) include those in which business-unit managers receive no bonus for the current year. Firms in the upper bound portfolio (UPP) are those in which business-unit managers earned their maximum available bonus. Firms in the middle bound portfolio (MID) cover those firms in which some, but less than the maximum available bonus is earned.
} 
logistic regression that takes the seriousness of the restatement into consideration. They report similar findings that suggest that the probability of a misstated financial statement increases significantly when the CEO holds a large number of in-the-money stock options. In addition, they find that the likelihood of a misstated financial statement increases when the firm is financially more constrained, raises new debt or equity capital, or has a CEO who also chairs the board of directors.

Other studies that examine equity incentives and the incidence of earnings restatements include Harris and Bromiley (2007) and Baber et al. (2009). The samples of these papers overlap completely in observation years, but report surprisingly different results. The former fails to find a relation between the incidence of accounting restatements and the ratio of option compensation to total compensation while the latter finds a positive statistical association between these variables.

\subsection{Equity incentives and accounting fraud}

Most of the aforementioned studies relate to compensation and financial reporting incentives. Yet, the body of research that examines real fraud or shareholder litigation is still relatively small to date. As indicated before, not all earnings management misleads investors and in turn leads to allegations of accounting fraud or shareholder litigation. Similarly, not all financial restatements indicate accounting irregularities. Rather, most of them are routine (Efendi et al., 2007). The GAO report (2002) states that the so-called accounting irregularities they identify do not rule out the unintentional misuse of facts applied to financial statements, arising from different interpretations of complex GAAP rules. The possibility that restatements may be made to correct unintended errors rather 
than dishonest misreportings clearly adds noise to any study that uses earnings restatements as a proxy for fraud. To counter this disadvantage and more accurately identify pernicious accounting fraud, some academic researchers examine firms that have actually been accused of fraud in the Accounting and Auditing Enforcement Releases (AAER) of the U.S. Securities and Exchange Commission (SEC). Dechow et al. (1996) point out that the agency only pursues cases where it can demonstrate that firms knowingly and intentionally engaged in accounting fraud.

Erickson et al. (2006) collect a sample of 50 firms that are both accused of fraud by the SEC action and for which they have compensation data during the period 1996 to 2003. They match these accused firms with two other firms not accused of fraud by industry (two-digit SIC code), year, and firm size (total assets). Applying unconditional logistic regression, they find no consistent evidence that executive equity-based incentives are associated with fraud. They also find no evidence that the managers of these fraudulent firms sell more stock or exercise more options during the alleged fraud period. Johnson et al. (2009) collect a sample of firms that were accused of fraud in connection with an AAER action by the SEC during the years 1992-2005. They match these accused firms with a sample of non-sued "innocent" firms that are in the same industry and have a similar size. ${ }^{12}$ Applying conditional logistic regression, they find that firms in which executives hold more unrestricted stocks and thus have a higher incentive to manage earnings are more likely to be investigated for fraud via an SEC action after

\footnotetext{
${ }^{12}$ In our study, we consider private securities class action lawsuits to proxy for an IPO firm's potential offer price inflation. While some prior studies (e.g.. Pukthuanthong, Turtle, and Walker, 2009) argue that some securities class actions may be unmerited and driven by opportunistic behavior on behalf of the plaintiffs and their law firms, they arguably provide a better proxy for securities fraud in an IPO context than earnings restatements or SEC actions. In fact, both earnings restatement and SEC actions are rare for IPO firms because prior to their IPO, issuing firms are not subject to the same disclosure requirements as publicly traded firms.
} 
controlling for firm governance, firm characteristics, and CEO characteristics. At the same time, however, the authors find no significant relationship between litigation risk and executive holdings of restricted stock and unvested and vested options. These results are in the contrast with Erickson et al.'s (2006) findings, which they attribute to the different methodology they use (conditional logistic regression rather than unconditional logistic regression). ${ }^{13}$

\subsection{Equity incentives and private securities litigations}

Other papers focus on actual litigations as identified by private securities litigations rather than SEC enforcement actions. The benefit of using private securities litigation as pointed out by Peng and Roell (2008) is that they capture a potentially broader set of manipulative activities, which are not limited to accounting fraud (e.g. they include misleading revenue projections, failure to disclose material information, etc.)

Denis et al. (2006) collect class action lawsuit data from the Securities Class Action Alert and Stanford's Securities Class Action Clearinghouse and executive compensation data from the Compustat Executive Compensation Database (ExecuComp) between 1993 and 2002 and report a significant positive relation between a firm's likelihood of being sued and the executive incentives from stock options. Furthermore, they consider outside blockholders and institutional ownership and find that the incentive provided by stock options to commit fraud is exacerbated by higher institutional and block ownership.

\footnotetext{
${ }^{13}$ Our results are robust to using either a conditional or unconditional logistic regression approach.
} 
Peng and Roell (2008) collect 479 class action lawsuits filed between 1996 and 2002 using the same databases as Denis et al. (2006). They find similar results that suggest that incentive pay in the form of options increases a firm's probability of being the subject of a securities class action after controlling for various firm characteristics.

Overall, prior empirical evidence in the extant literature in this area tends to favor the view that there is a "dark side" of executive incentives, which leads to unintended or adverse consequences and a cost for shareholders.

\section{Underlying theory and hypothesis development}

Becker's (1968) economic theory of crime suggests that a person commits fraud not because his basic motivation differs from that of others, but because his benefits and costs differ. A similar framework has been used by Efendi et al. (2007), Denis et al. (2006), and Johnson et al. (2009). By focusing on the role of the CEO as a self-interested agent, we assume that the decision to commit fraud is influenced by the top executive's personal assessment of the expected payoffs from the fraud less the expected costs associated with the detection of the fraud. In particular, similar to Denis et al. (2006), we hypothesize that the expected payoffs are affected by the executive's compensation and equity ownership structure. Consistent with the information asymmetry theory, we further assume that insiders, who have more information than outsiders - especially for an IPO firm which has never been public before - are able to deceive the market to inflate the offer price by manipulating company information. 
Executives may be granted options prior to the IPO (pre-IPO options) or at the time of the IPO (IPO options). Fife (1995, pg. 64) points out that "before an IPO, major value-creating initiatives include developing new products and markets, obtaining regulatory approvals, increasing the size and quality of earnings, exhibiting a strong growth pattern and establishing a credible management team." All these actions are expected to generate interest among potential investors and thus produce high price multiples at the IPO. However, Fife also notes that executives will only be motivated to increase the firm's marketable value when they receive pre-IPO options (which usually have a discounted exercise price), but not through IPO options (for which the exercise price equals the offer price) as IPO options will not incorporate the value that management generated prior to the offering. In other words, the executives will not be rewarded for the value increase that took place prior to the IPO by receiving an IPO option grant. Therefore, executive pre-IPO options as well as equity ownership tie an executives' wealth to the firms' stock price and in turn provide the executive with the financial incentive to inflate the company's offer price. As pre-IPO stock option grants and equity ownership increase, the expected payoff from fraud increases. IPO options may not provide incentives for executives to inflate the offer price; however, we add a dummy variable to control for their effect if any.

All firms may engage in value-creating activities prior to their IPO and show the results of those activities in the registration statements to the public. Investors will rely on that information to value the price of the company's stock. By using private securities litigation to identify fraudulent firms, we focus on cases in which executives cross the threshold within which there are no criminal or civil penalties for value-creating 
activities. This distinction is important because in many cases, it is impossible to observe managerial fraud. We infer manipulation from observing "extreme" outcomes (legal action) where manipulation is likely to have occurred. One concern with this measurement method is that in some cases, it may incorrectly classify a firm as fraudulent even though the lawsuit against it was unmerited. Similarly, if fraud was committed but not revealed, then a firm may be classified as innocent. The potential for misclassification is a limitation of our study as well as previous studies that use accounting restatements or information on SEC AAER actions to identify fraud.

Based on the discussion above, we propose the following hypothesis:

Hypothesis 1: IPO firms in which a CEO has higher equity incentives face a higher risk of litigation than comparable firms in which a CEO has less equity incentives.

Effective monitoring of the CEO by the board of directors is likely to reduce the incidence of a lawsuit. Hermalin and Weisbach (1998) indicate that board effectiveness is a function of its independence and the greatest factor affecting the effectiveness is the board's independence from the CEO. However, in many companies, the CEO also serves as chairman of the board. Jensen (1993) argues that a CEO cannot perform the chair's monitoring function apart from his or her personal interest and argues that as a result, it is important to separate the roles of chairman and CEO. In line with this argument, Efendi et al. (2007) find that accounting restatements are more likely to be made by firms in which the CEO serves as chairman of the board of directors. 
Boards which are dominated by inside directors lack the monitoring by outside directors, and in turn may be more likely to manipulate information. Along those lines, Dechow et al. (1996) find that firms accused of accounting fraud by the SEC are more likely to have insider-dominated boards. Similarly, Beasley (1996) finds that a greater percentage of outside directors correlates with a lower likelihood of fraud. However, Agrawal and Chadha (2005) and Johnson et al. (2009) do not find outside directorship to significantly reduce the likelihood of accounting fraud or earnings restatements. Based on the discussion above, we propose the following two hypotheses:

Hypothesis 2: IPO Firms in which boards are dominated by insiders face a higher risk of litigation than comparable firms.

Hypothesis 3: IPO Firms in which a CEO holds the position of board chairperson face a higher risk of litigation than comparable firms.

\section{Data}

\subsection{IPO and litigation data}

During our sample formation, we consider all initial public offerings from January 1, 1997, to December 31,2007 , as identified in the Global New Issues database of Thomson Financial's Security Data Company (SDC). IPOs by closed-end funds, REITs, financial firms (with SIC codes ranging from 6000 to 6900), unit offerings, reverse LBOs, spinoffs, ADRs, and foreign issues are excluded as their institutional 
characteristics are fundamentally different from those of a typical IPO firm. ${ }^{14}$ After these exclusions, our dataset contains a total of 2,268 IPOs.

Firms that faced a class action suit are identified through Stanford University's Securities Class Action Clearinghouse (http://securities.stanford.edu) and the Securities Class Action Alert. After reading the summary of each case, we only collect IPO-related lawsuits, defined as suits that allege fraud relating back to disclosures made prior to the IPO and that include the IPO date in the class period (Choi, 2007). We exclude class action suits brought as part of the recent wave of IPO laddering litigations in which underwriters, rather than issuers, are alleged to be the principal wrongdoers. ${ }^{15}$ For each case, we also collect the lawsuit filing date, the class action period, and the case summary. Among the 2,268 firms in our 1997-2007 IPO sample, we identify 86 firms that were sued in connection with their IPO. Court dockets for these cases were obtained from the Public Access to Court Electronic Records (PACER) database, a web-based service by the U.S. department of Justice that provides access to case information online. (http://pacer.psc.uscourts.gov).

\subsection{Matching procedure}

We match each of the 86 firms in our sued IPO sample with a non-sued control firm that was not the subject of an IPO-related class action lawsuit using the following

\footnotetext{
${ }^{14}$ SIC codes ranging from 6000 to 6999 represent financial service companies facing different regulations than other firms (Choi, 2007). Spin-off IPOs and reverse LBOs may present companies with different financial needs and different managerial objectives than other IPOs. Foreign issuers are excluded as we concentrate on domestic IPOs. A unit represents a combination of securities, such as common stock and warrants and is therefore excluded.

${ }^{15}$ In a laddering litigation, plaintiffs generally contend that underwriters engaged in illegal tactics by either receiving undisclosed greater compensation from investors or requiring investors in IPOs to agree to purchase additional shares immediately following the IPO at pre-determined prices to artificially inflate the price of the stock.
} 
matching procedure. First, for each sued IPO firm we identify all non-sued IPO firms in the same industry based on the firm's two-digit SIC code. Second, we only select firms that had their IPO during the same IPO year as the sued firms. Finally, out of these industry-and-year matched firms we choose the firm that is closest to the sued firm in terms of total assets in the most recent fiscal year prior to the IPO (used as a proxy for size). If the total assets of the control firm are not within $50 \%$ of the total assets of the sued IPO firms, we drop the observation. Using this matching procedure, we find matching firms for 81 of our sued IPO firms. Therefore, we get our final sample of 162 firms.

\subsection{Executive compensation data}

We hand-collect executive compensation data from each firm's IPO prospectus (424B form) and proxy statement as posted on the SEC's Electronic Data Gathering and Retrieval (EDGAR) system. In addition, we use prospectuses and proxy statements to obtain information on options held by the chief executive officers at the time immediately prior to the IPO. A pre-IPO option is defined as an option issued prior to the IPO, and whose exercise price is not directly linked to the IPO offer price. Similar to Lowry and Murphy (2007), an IPO option is defined as an option whose exercise price is directly linked to the IPO offer price. In some cases, options granted several days before the IPO date are also treated as IPO options rather than pre-IPO options if their exercise price is explicitly linked to the offer price. In some slightly ambiguous cases (e.g., the exercise price is $80 \%$ or $110 \%$ of the offer price), we refer to the text of the prospectus to determine whether it was in fact an IPO option or a pre-IPO option. 
Executive ownership data is also obtained from the IPO prospectus. Specifically, we collect information on the number of shares owned by the chief executive officer prior to the IPO. In order to better capture the CEO incentives from equity ownership, we include not just information on the CEO's direct ownership but also on the ownership by the CEO's immediate family members, and shares in trusts associated with the CEO.

We also collect details on firm and offer characteristics including the issue date, firm auditors and underwriters, the registered dollar amount of the offer, as well as information on VC backing and the exchange where a firm lists from the SDC and verify the accuracy of the respective data with information contained in each firm's prospectus. ${ }^{16}$ Governance variables including board size, the percentage of insiders on the board, a CEO-chair dummy, and CEO traits including CEO age, CEO tenure, and a CEO founder dummy are collected from the IPO prospectus. Accounting variables including total assets (TA), operating income before depreciation (OIBD), total debt (TD), tangible assets (PPE), and R\&D expenses are collected from Compustat, with missing data filled in according to data in the IPO prospectus. Finally, first-day closing prices are collected from the Center for Research on Security Prices (CRSP) database.

\subsection{Characteristics of IPO lawsuits}

Table 1 provides information on the distribution of all IPOs as well as our subsample of sued IPOs across years and industries. From Panel A, we can observe that IPO volume was highest in 1997 with 477 IPOs and reached its lowest level in 2003 with 54 IPOs. Only $2 \%$ of the IPO firms that went public in 2003 were subsequently sued

\footnotetext{
${ }^{16}$ We thank Jay Ritter for making data on underwriter ranks and firm ages available on his website (http://bear.cba.ufl.edu/ritter/ipodata.htm) .
} 
compared with over $6 \%$ of the 2007 IPOs. Similar to the findings of Lowry and Shu (2002), we find no systematic relation between the total number of IPOs and the number of lawsuits against IPO firms although they vary over the sample period. From Panel B, we find that 47 lawsuits out of the 81 cases in our sued IPO sample are against firms in the communications, computers, and electronics industry. Not surprisingly, this industry has the highest volume of IPO (979 IPOs). On a percentage basis, about $4.8 \%$ of the IPO firms in this industry were ultimately sued. Interestingly, IPO firms in the apparel industry faced the highest litigation risk (16.7\%) during our sample period.

*** Insert Table 1 about here ***

Table 2 provides more detailed information regarding the lawsuits filed against our sample firms. Panel A gives details on the nature of the primary alleged fraud in each complaint. The vast majority of suits allege "material misstatements" and "failure to disclose relevant information". ${ }^{17}$ Specifically, "failure to disclose material adverse information and known risks", and "overoptimistic forecasts" represent a big portion of the claims (nearly $40 \%$ ). Another nearly $40 \%$ of all sued firms are accused of misrepresenting their financial condition, engaging in earnings manipulations or violating GAAP standards. In each case, the firm is accused of having undertaken those actions in an attempt to fraudulently boost the company's offer price.

*** Insert Table 2 about here $* * *$

${ }^{17}$ This finding is consistent with the observation of DuCharme et al. (2004) regarding IPO and SEO related securities class action litigation. 
Panel B of Table 2 describes the outcome of our sample lawsuits. Forty-three of the 81 suits were settled, 24 were dismissed or withdrawn, and 13 were still pending as of the end of 2008. There is one case for which we are unable to determine the outcome.

\section{*** Insert Figure 1 about here $* * *$}

Panel $\mathrm{C}$ of Table 2 provides information on the timing of our sample lawsuits. In addition, Figure 1 depicts a typical time line for an IPO-related securities class action. The class action period starts on the IPO date when the final prospectus is issued. The mean and median lawsuit in our sample has a class period (a period during which the shareholders were negatively affected by the alleged fraud) of 229 and 173 days, respectively. The median number of days from the start (end) of the class period to the filing date is 274 (25) days, respectively. The time line varies significantly across lawsuits: $25 \%$ of the lawsuits have a class action period of less than 80 days while $25 \%$ of the lawsuits have a class action period of more than 293 days. Regarding the length of time between the IPO date and the filing date, $25 \%$ of the lawsuits are filed in less than four months while another $25 \%$ are filed after more than 444 days. Typically, lawsuits are required to be filed within three years after the initial public offering. However, our sample contains two lawsuits that are filed more than three years after the IPO and the maximum time from the offer date to the lawsuit filing date is 1,172 days, which is a little more than three years and two months. ${ }^{18}$ Furthermore, we find that 50 out of our 81 cases are filed within one year of the IPO, 25 in the second year after the IPO, and 6 in the third year or afterwards.

\footnotetext{
${ }^{18}$ The three-year deadline for lawsuit filings (also referred to as the statute of litigations) may be extended when the plaintiffs can show that they did not become aware of the alleged securities fraud until well after the IPO.
} 


\section{Methodology}

\subsection{Main model}

We begin by using conditional paired logistic regression to determine which of the hypothesized explanatory variables affect the incidence of IPO-related lawsuits, comparing 81 sued companies to the 81 " innocent" firms. Specifically, we consider the following logistic regression model:

$$
\begin{aligned}
& \text { Suit }_{i}=\beta_{0}+\sum_{k=1}^{K} \beta_{k} * \text { Equity Incentives }_{k i}+\sum_{m=K+1}^{M} \beta_{m} *{\text { governance } \text { variables }_{m i}+}^{N} \\
& \sum_{n=M+1}^{N} \beta_{n} X_{n i}+\varepsilon_{i} \text { (1) }
\end{aligned}
$$

Where Suit is equal to one if there is a lawsuit, and zero otherwise. Equity incentives include incentives from pre-IPO options and equity ownership; the governance variables include a CEO-Chairman dummy and the percentage of insiders on the board, and $X_{M+1, i} \ldots X_{N i}$ are a variety of control factors and other variables of interest that we hypothesize to influence an IPO firm's litigation risk.

Burns and Kedia (2006) suggest that incentives for accounting fraud should be associated with the use of stock options beyond the desired level. They refer to the "excessive" use of options as the abnormal option sensitivity of the CEO's compensation package. Similar to Burns and Kedia, we perform additional tests in which we adopt a two-stage estimation procedure to measure the CEO's abnormal option and equity sensitivity. A preliminary correlation analysis suggest that several control variables in our model are correlated with pre-IPO options and equity ownership, which suggests that they may also be determinants of the CEO's compensation structure (salary and bonus) and equity ownership. To find the appropriate factors that can determine the desired level of equity incentives, we refer to John and John (1993), Kedia and Mozumdar 
(2002), and Weber and Dudney (2003) and regress the CEO's equity incentives and compensation on CEO age, CEO tenure, company age, board size, a CEO founder dummy, a CEO chair dummy, total assets, R\&D, leverage, tangibility, profitability, and a VC-backing dummy as follows (first stage):

Equity Incentives $=$

$\alpha_{0+} \alpha_{1} \ln ($ CEO age $)+\alpha_{2} \ln (1+$ CEO tenure $)+\alpha_{3} \ln (1+$ company age $)+\alpha_{4} \ln ($ board size $)+$ $\alpha_{5}$ founder dummy $+\alpha_{6}$ CEO Chair dummy $+\alpha_{7} \ln ($ total assets $)+\alpha_{8} R \& D / T A+\alpha_{9} T D / T A+$ $\alpha_{10} P P E / T A+\alpha_{11} O I B D / T A+\alpha_{12} V C d u m m y+\varepsilon(2)$

$\operatorname{Ln}($ bonus $)=$

$\alpha_{0+} \alpha_{1} \ln (C E O$ age $)+\alpha_{2} \ln (1+$ CEO tenure $)+\alpha_{3} \ln (1+$ company age $)+\alpha_{4} \ln ($ board size $)+$ $\alpha_{5}$ founder dummy $+\alpha_{6}$ CEO Chair dummy $+\alpha_{7} \ln ($ total assets $)+\alpha_{8} R \& D / T A+\alpha_{9} T D / T A+$ $\alpha_{10} P P E / T A+\alpha_{11} O I B D / T A+\alpha_{12} V C d u m m y+\varepsilon(3)$

$\operatorname{Ln}($ salary $)=$

$\alpha_{0+} \alpha_{1} \ln ($ CEO age $)+\alpha_{2} \ln (1+$ CEO tenure $)+\alpha_{3} \ln (1+$ company age $)+\alpha_{4} \ln ($ board size $)+$ $\alpha_{5}$ founder dummy $+\alpha_{6}$ CEO Chair dummy $+\alpha_{7} \ln ($ total as $s)+\alpha_{8} R \& D / T A+\alpha_{9} T D / T A+$ $\alpha_{10} P P E / T A+\alpha_{11} O I B D / T A+\alpha_{12} V C d u m m y+\varepsilon(4)$

The residuals from these cross-sectional regressions represent the portion of salary and bonus compensation as well as equity incentives that are unexplained. We therefore include each of these residuals as the explanatory variables in the second stage logistic regression.

$$
\begin{aligned}
& \text { Suit }_{i}=\beta_{0}+\sum_{k=1}^{K} \beta_{k} * \text { abnormal incentives }_{k i}+\sum_{m=K+1}^{M} \beta_{m} * \text { governance variables }_{m i} \\
& +\sum_{n=M+1}^{N} \beta_{n} X_{n i}+\varepsilon_{i} \text { (5) }
\end{aligned}
$$




\subsection{Variable measurement}

In this section we first describe our measures of CEO compensation and CEO incentives that are related to litigation risk. In addition, we define other variables that are used to control for known determinants of litigation risk. For a comprehensive overview of all variables used in this study and their sources, please refer to Appendix 1.

\subsubsection{Executive compensation and equity ownership variables}

The compensation and incentive variables we examine are cash compensation and equity incentives, including incentives from equity ownership and incentives from preIPO options.

Following Cheng and Warfield (2005), pre-IPO option incentives are measured as the number of shares underlying pre-IPO options deflated by total shares outstanding (pre-IPO) of the firm.

Similar to option incentives, incentives from CEO ownership are measured as the number of shares held by the CEO (including the CEO's immediate family members, and shares in trusts associated with the CEO) as a fraction of shares outstanding prior to the IPO.

The aggregate $\mathrm{CEO}$ incentives arising from options and shareholdings are the sum of incentives of each element (Conyon and Murphy, 2000; Denis et al. 2006; Bergstresser and Philippon 2006), i.e. they are defined as follows: 
Aggregate CEO incentives $=$ incentives from pre $-I P O$ options + incentives from pre -

IPO stock ownership (6)

CEO shareholdings and pre-IPO options benefit from a higher offer price as the inflated price gives the CEOs a potential gain from liquidating his positions after the lockup period, holding the aftermarket price constant. To measure the magnitude of the number of pre-IPO options and equity holdings, we compute the hypothetical gains from each $\$ 1$ increase in the offer price (holding the aftermarket price constant) as follows: ${ }^{19}$ $E x-$ ante gain from manipulating information $=$ number of pre $-I P O$ option holdings + number of pre - IPO equity holdings (7)

The variable Bonus captures the bonus awards to executives during the year prior to the IPO and is measured as $\operatorname{Ln}(1+$ bonus $)$. The variable Salary represents the salary received by executives during the year prior to the IPO and is measured as $\operatorname{Ln}(1+$ salary). Salary is a minimum fixed payment a manager receives irrespective of the performance of the company within a given year. By this definition, salary levels are not linked to changes in the firm's stock price. Therefore, we expect no association between salary and

\footnotetext{
${ }^{19} \mathrm{We}$ assume that the delta of the pre-IPO options in the executive's portfolio is equal to one. One may argue that this is approximately true for options that are deep in the money, but it is less accurate for options that are out of the money. However, since there is no public market trading before the IPO, it is not feasible to estimate the delta for pre-IPO options using Black-Scholes' (1973) formula without knowing the stock price. Another problem that prevents us from calculating the options' delta is that from the prospectuses and proxy statements, we cannot find all the information on past option grants such as the exercise price and the time to maturity. Lowry and Murphy (2007) point out that options issued prior to an IPO often carry nominal exercise prices (such as 10 cent to $\$ 1.00$ ) that are seldom challenged by the SEC, IRS, or FASB as being below fair market value. Many pre-IPO options in our sample have extraordinarily low exercise prices and the average exercise prices of the pre-IPO options in our sample are much lower than the offer price (assuming the offer price is the current market price when measuring delta); therefore, the assumption that the delta of the executive's option portfolio equals one is unlikely to bias our results in any significant way. To further assure that the delta of pre-IPO options is close to one, we use similar backof-the-envelope calculations as those used by Lowry and Murphy (2007) to estimate delta. Our results suggest that the deltas of pre-IPO options are indeed very close to one.
} 
the likelihood of fraud. Prior studies such as those by Denis et al. (2006) and Peng and Roell (2007) do not detect any relation between bonuses and the incidence of litigation. Peng and Roell attribute the lack of a significant relation to the fact that the impact of bonuses is small relative to the impact of options after firms started to shift from bonus to option plans in the 1990s. Regarding bonus plans, Gao and Shrieves (2002) point out that they are highly firm-specific and that it is difficult to obtain information on how or whether the structure of a given bonus plan changes after the IPO. Therefore, we do not make any predictions regarding the sign and magnitude of the association between bonuses and litigation risk.

\subsubsection{Control variables}

In our litigation risk model, we control for auditor and underwriter quality. The extant literature suggests that there is less uncertainty surrounding issues whose values are certified by high quality players (cf., Ritter, 1984; Carter and Manaster, 1990; Michaely and Shaw, 1994). Underwriters and auditors may have valuable reputations to protect; therefore, they may have incentives to completely fulfill their fiduciary duty and precisely portray information regarding the value of the IPO firm (cf., Lowry and Shu, 2002). Thus, offers involving prestigious underwriters or auditors may be unlikely to attract a lawsuit. However, as underwriters and auditors can also be named as codefendants, the 'deep pockets' theory (Alexander, 1991) suggests that prestigious underwriters or auditors attract more lawsuits as plaintiffs may get more potential benefits. ${ }^{20}$

\footnotetext{
${ }^{20}$ Note that we exclude laddering cases in which underwriters are listed as lead defendants, but that we do not exclude cases in which underwriters are named as co-defendants alongside offering firms.
} 
We further control for offer size. As such, we follow Ducharme et al. (2004) who find that if the offer is small, the potential loss to investors is also small. They argue that the fixed costs of litigation will discourage investors to sue a firm over a small offer. Thus, small offers reduce the possibility of IPO firms being sued.

In line with the information asymmetry theory, IPOs backed by venture capitalists are generally expected to have better governance and operations and thus face a lower risk of being sued. However, the 'deep pockets' argument made above can also be extended to venture capital backed IPO firms as shareholders can potentially recover damages from a venture capitalist (Lowry and Shu, 2002). We capture this effect by adding a dummy variable to our model that equals 1 if the IPO is venture capital backed and 0 otherwise.

In addition, we add a dummy variable for IPO options, namely, options issued to executives on the IPO date with an exercise price that equals the offer price. The effect of IPO options on the likelihood of managerial fraud may be ambiguous. Past literature argues that executives purposefully lower their firm's offer price to have a lower option exercise price although the empirical evidence is inconsistent. IPO options may thus reduce the likelihood of executives committing fraud as the inflated offer price also inflates the exercise price, which provides no benefit to the executives.

Furthermore, we include IPO underpricing as measured by the percentage return from the offer price to the first-day closing price as a control variable. This variable is added based on the litigation-risk hypothesis (see, for example, Logue, 1973; Ibbotson, 1975; Tinic, 1988; and Lowry and Shu, 2002). Under the deterrence effect of the 
litigation risk hypothesis (Lowry and Shu, 2002), firms have an incentive to underprice their shares to reduce the likelihood of future litigation brought against them by investors whose wealth is damaged by the poor performance of the firm's stock.

We control for firm characteristics and offer characteristics. Specifically, we control for firm size, asset tangibility, firm age, leverage, growth opportunities, and profitability at the end of last fiscal year prior to IPO. Older firms tend to perform better both before and after the IPO (Ritter 1998). Therefore, we expect younger firms to be riskier and to be sued more often. We include leverage measured by total debt scaled by total assets to control for the possibility that financially distressed firms have stronger incentives to commit fraud than firms that are not distressed (Begley et al., 1996; Erickson et al., 2006). Asset tangibility, measured as tangible assets divided by total assets, is added based on the argument that firms with more tangible assets, on average, have more stable earnings and are, therefore, less risky (Titman and Wessels, 1988). We include $R \& D$ expense as a proxy for growth opportunities and operating income over assets as a proxy for profitability. Wang (2005) in his theoretical model shows that a firm's propensity of committing fraud is positively related to growth potential and negatively related to the profitability of the firm's current assets.

We also control for CEO characteristics such as CEO age, CEO tenure, and a dummy that indicates whether the CEO is a founder. CEO with a longer tenure may have more power to influence other executives to help commit fraud and older CEOs who are closer to retirement may incur smaller reputational damages if caught committing a crime, and may therefore be more likely to commit fraud (John et al., 2009). On the other 
hand, new CEOs may have limited knowledge of the firm and may therefore lack the ability to deter fraud or be over-optimistic regarding the firm's prospects. Therefore, we expect a positive relation between CEO age and the risk of litigation but do not provide prediction regarding the relation between $\mathrm{CEO}$ tenure and litigation risk. A founder CEO may overestimate the strength and long-term prospects of their firms, which may result in poor management decisions (cf., Certo et al., 2001). This over-optimism may lead to a higher risk of litigation. Finally, we include an exchange dummy. Firms listed on the Nasdaq are often viewed as being more risky which is likely to increase these firms' legal exposure (Lowry and Shu, 2002).

\section{Empirical results}

\subsection{Descriptive statistics and univariate tests}

Table 3 reports descriptive statistics and provides results for a series of univariate tests used to compare the characteristics of sued and non-sued firms. Note that the univariate comparisons are only descriptive in nature because they implicitly assume that other potentially relevant factors are fixed, which may not be the case. Therefore, our main inferences are based on the multivariate tests performed later.

\section{*** Insert Table 3 about here $* * *$}

Panel A of Table 3 describes the compensation and ownership characteristics of our sample firms. The corresponding test results suggest no significant difference between the incentives CEOs derive from pre-IPO options in sued or non-sued firms although the mean and median sued firm values are higher than those of non-sued firms. However, the mean incentives from pre-IPO ownership are significantly higher at the 5\% 
level in sued firms than in non-sued firms. We find that $20 \%$ of the CEOs in sued firms own IPO options compared to $27 \%$ of the CEOs in non-sued firms. However, the difference is not statistically significant. The mean ex-ante gain from a dollar increase in the offer price for sued firms is 4.41 million compared to 2.51 million for non-sued firms. The difference is statistically significant at the 5\% level. The data in Panel A reveal few differences in the bonus structure between sued and non-sued firms. However, the mean and median CEO salary is significantly higher at the $5 \%$ level in sued firms than in nonsued firms (262 thousand and 227 thousand, respectively, for sued firms, compared to 219 and 205 thousand for non-sued firms).

Panel B of Table 3 provides information regarding IPO characteristics. The mean and median offer size of the sued-firm IPOs is about $\$ 106$ million and $\$ 77$ million, respectively, compared to $\$ 80$ and $\$ 60$ million, respectively, for non-sued IPOs. The difference is statistically significant at the $5 \%$ level in both the mean and median. The initial underpricing return equals $13.54 \%$ for sued firms and $13.41 \%$ for non-sued firms. Consistent with the findings of Lowry and Shu (2002), there is no significant difference between the initial return of sued and non-sued firms from the univariate test. In addition, we do not find any significant differences between sued and non-sued firms in terms of auditor quality, underwriter rank, VC-backing or exchange listing (NASDAQ vs. nonNASDAQ).

Panel $\mathrm{C}$ of Table 3 describes the firm characteristics of sued and non-sued firms for the most recent fiscal year prior to the offering date. The average sued firm in the sample is 9.5 years old (vs.7 years for non-sued firms), has assets and revenues of $\$ 133.7$ 
and $\$ 100.8$ million, respectively (vs. $\$ 100.6$ and $\$ 82.7$ million for non-sued firms, respectively), was financed $32 \%$ by debt (vs. $24 \%$ for non-sued firms), and had a tangibility ratio of $22 \%$ (vs. $19 \%$ for non-sued firms). The sued firms have an average operating income over total assets of $-18.02 \%$ (vs. $-27.26 \%$ for non-sued firms) and have a R\&D ratio of $20 \%$ (vs. $18 \%$ for non-sued firms). None of the differences in the mean and median values of sued and non-sued firm characteristics are statistically significant except for the leverage ratio. The higher leverage ratio for sued firms may suggest that sued firms tend to be more likely to be financially distressed and thus face a higher litigation risk.

Finally, Panel D of Table 3 provides information on CEO traits and characteristics the board of directors. Founders lead $41 \%$ of the sued firms and $37 \%$ of non-sued firms. CEOs chair about $51 \%$ of sued-firm boards and $53 \%$ of non-sued-firm boards. The average board size is 6.6 for sued firms and 6.9 for non-sued firms. The CEOs are on average 48 years old with a tenure of 4.5 years for sued firms and on average 46 years old with a tenure of 5.3 years for non-sued firms. None of the differences in the mean and median values of these variables above are statistically significant. However, the boards

in sued firms tend to be dominated by inside directors (32\% on average, compared to $27 \%$ for non-sued firms). The difference is statistically significant at the $5 \%$ level.

\subsection{Regression results (with normal equity incentives)}

Table 4 reports the results of a conditional logistic regression estimating the effect of CEO incentives and a variety of other factors on the incidence of shareholder lawsuits. The parameter estimates do not include an intercept because it is impossible to uniquely 
identify an intercept in a 1:1 matched pair conditional logistic regression. Based on the likelihood ratio chi-square statistics, all models are significant at the 10 percent level except for model five, whose p-value is 0.14 . The pseudo $R^{2}$ is similar in magnitude across all models. We measure CEO incentives in two models, a full model and a parsimonious model. In the parsimonious model, we include variables which are generated from a stepwise logistic regression and other interested variables.

In model 1 and 2, we focus our attention on a CEO's aggregate equity incentives. As expected, the sign of the coefficients for equity incentives for the full model and the parsimonious model are positive, indicating a positive relationship between a CEO's aggregate equity incentives and the incidence of shareholder litigation. The relationship is statistically significant at the five percent level in both the full (model 1) and parsimonious model (model 2). As we use shareholder litigation as a proxy for a CEO's misconduct during the IPO process, we interpret our result that CEOs who have more aggregate equity incentives are more likely to manipulate information during the IPO process and inflate the offer price. When we divide the aggregate equity incentives into incentives that are derived from pre-IPO options and incentives form pre-IPO equity ownership (model 3 and 4), we find consistent results. Both pre-IPO options and pre-IPO equity holdings provide an incentive to CEOs to manipulate information and inflate the offer price. When we measure the incentives derived from pre-IPO options and equity holdings in terms of the ex-ante gain a CEO would derive from a hypothetical one dollar increase in the offer price (model 5 and model 6), we get similarly significant results. In general, hypothesis 1 is supported by our results. In terms of cash compensation, the signs of the coefficients for salary and bonuses are both negative, indicating that cash 
compensation mitigates the incidence of fraud. However, consistent with previous findings, this relationship is insignificant in most of the models (Model 3 suggests a marginal significance for bonuses at a $10.7 \%$ and Model 4 at a $12.7 \%$ significance level). While we hypothesize that the expected payoffs of CEOs from manipulating information are affected by their compensation and equity ownership structure, the probability of detection is affected by the composition of the board of directors. We find a positive relationship between insider-dominated boards and the incidence of shareholder litigation (hypothesis 2). The relationship is significant in most of the models except for model 1 and 3. This result indicates that firms that have a higher proportion of top managers on the board are more likely to face securities class action litigations, possibly because insider-dominated boards are more likely to comply with the CEO's decision and that the lack of outside directors' monitoring increases the likelihood of company fraud. Efendi et al. (2007) find evidence that suggests that combining CEO and board chair positions increases the likelihood of accounting irregularities. In contrast, we do not find a significant relationship between our CEO-Chairman dummy and the likelihood of shareholder litigation. As such, our results are more in line with Agrawal and Chadha (2005) who find no relation between these variables for seasoned firms and Agrawal and Cooper's (2009) results for IPO firms.

Another interesting finding in Table 4 is that there is a significant relationship between CEO traits and the incidence of shareholder litigation. We find that CEO age is positively related to the likelihood of shareholder litigation at the five percent significance level in Model 1 and Model 5, and at the one percent level in all other models. This result is consistent with our prediction that younger CEOs may be more 
concerned about their reputation which is a valuable asset for their future career. Therefore, younger CEOs tend to manipulate information less frequently during the IPO process, leading to a reduced possibility of shareholder litigation. In terms of the relation between the length of tenure and the incidence of litigation, we made no prediction on the expected sign. However, our findings strongly suggest that the length of CEO tenure is significantly negatively related to the incidence of shareholder litigation throughout all of our models. We offer two explanations for this result. Due to the limited knowledge about the firm possessed by the new CEOs, they may lack the necessary insight to spot and deter fraud if it is committed by other officers and may be over-optimistic regarding the firm's prospects, which - when uncovered - may lead to shareholder litigation. In addition, the founder CEO variable is positive and statistically significant in all models. This indicates that founder-led IPO firms are more likely to be sued. We argue that the higher litigation risk for firms led by founder CEOs is likely caused by the fact that founder CEOs tend to lack the business expertise and training a hired professional CEO typically brings to the job and may overestimate their firms' prospects.

We find no significant relationship between most accounting variables and litigation risk except for the leverage ratio which is positively related to the litigation risk at the ten percent significance level in most models. The intuitive interpretation for this result is that highly leveraged firms may have more incentives to misreport the firm's prospects to raise more capital through the equity offering to repay their debt obligations. In addition, the higher debt burden increases the firm's likelihood of financial distress. We find no significant relationship between the level of underpricing and litigation risk in our matched pair sample, which does not support the deterrence effect of the litigation- 
risk hypothesis (Lowry and Shu 2002). In addition, the IPO option dummy, the VCbacking dummy and auditor ranking are insignificant. Consistent with the "deep pocket" theory and similar to the findings of DuCharme et al. (2004), we find some evidence that underwriter rank is positively related to the incidence of shareholder litigation. Finally, we find some evidence that lawsuits are positively related to offer size (Model 2, 3 and 4), which may be caused by the fact that investors are not eager to sue a firm over a small offer given the fixed cost of litigation.

\subsection{Regression results (with abnormal equity incentives)}

In Table 5, we focus our attention on abnormal equity incentives. As discussed in our methodology section, abnormal equity incentives are incentives that go beyond the desired level and cannot be explained by factors such as CEO age, CEO tenure, firm characteristics, and etc. We expect the "excessive" incentives from pre-IPO options and pre-IPO equity ownership to be positively related to CEO misconducts during the IPO process that subsequently lead to shareholder litigation. The coefficient of abnormal equity incentives is positive and significant at the five percent level in all models. The results for all other variables are similar to those in Table 4. In general, our results suggest that CEOs whose incentives from pre-IPO options and equity ownership deviate from optimal incentive levels during the IPO process are more likely to be associated with sued firms.

\subsection{Regression results high tech firms vs. non-high tech firms}

As our sample is dominated by technology stocks, our results may be influenced by some special traits of high tech firms. To ensure the robustness of our results, we 
therefore partition our sample of sued firms into two groups: high tech firms and nonhigh tech firms. We then re-estimate the models separately for each subsample. Due to the matching criteria we employ in our analysis, (we matched by 2-digit SIC codes), some control firms of high tech sued firms are not actually high tech firms. By the same token, some control firms of non-high tech sued firms are actually high tech firms. Therefore, we lose some observations which in turn reduces the number of matched pairs in both subsamples. To have a more accurate and strict definition of high tech firms, we refer to the AeA definition to indentify firms in the high tech industry (see Appendix 2).

The results of the sub-sample tests are reported in Table 6. Interestingly, we find some significant differences in the results between the high tech and non-high tech subsample. In terms of equity incentives, we find a significant association between equity incentives and the incidence of shareholder litigation in all models for the high tech subsample although the significance level is reduced compared with the full sample test results in Table 4 and 5. In contrast, equity incentives in the non-high tech subsample are consistently insignificant although the signs of the coefficients are positive as expected. In the high-tech subsample, we find some evidence to support the deterrence effect of the litigation risk hypothesis (Lowry and Shu, 2002). The initial return of high tech firms is negatively related to the incidence of lawsuit at litigation at the ten percent significance level (models 1 and 2), suggesting that higher underpricing reduces the likelihood of firms being sued. In addition, the length of CEO tenure and the leverage ratio are only significant in the high tech sub-sample. We find only weak evidence that insiderdominated boards increase a firm's litigation risk. Underwriter ranking and the CEO founder dummy are insignificant in all models although the sign of the coefficient is 
unchanged when compared with the full sample results. Lastly, CEO age is positively related to litigation risk in both the high tech subsample and the non-high tech subsample.

Overall, our results suggest that the positive association between CEO equity incentives and litigation risk is only pervasive for high tech firms. In addition, the length of CEO tenure and the leverage ratio appear to be related to incidence of shareholder litigation only in high tech firms. Furthermore, high tech firms tend to underprice their shares more to avoid future litigation. CEO age appears to be significantly related to litigation risk for both subsamples as well as the full sample.

\subsection{Regression results non-accounting related fraud $v$ s. accounting related fraud}

In Table 2, we can see that a significant portion of the lawsuits in our sample allege that the company failed to disclose material adverse information or risks and/or made overoptimistic forecasts. Such claims are clearly different from cases that allege accounting fraud and one may argue that top executives may not intentionally hide risks or make overoptimistic forecasts, but instead simply fail to realize the potential risk of their firms or are over-confident about their firms' prospects. Intuitively, accounting related fraud seems to be more closely associated with CEO incentives. In order to examine whether non-accounting related fraud is also associated with CEO incentives, we partition the full sample of sued cases into two groups: accounting related cases and non-accounting related cases.

Table 7 reports the results for the respective subsample tests. As expected, the CEO equity incentives are positively related to the incidence of accounting-related shareholder litigation. However, we also find evidence that CEO equity incentives are 
positively associated with the incidence of non-accounting related shareholder litigation (models 4 and 5) although the significance level is lower than that in the accountingrelated subsample. In terms of other variables, the two subsamples generate different results. Only CEO age is significantly positively related to the incidence of accounting and non-accounting related lawsuits for both samples.

\subsection{Additional sensitivity analyses}

To examine the robustness of our results, we conduct various sensitivity tests. Our results are reported in Table 8. First, we re-estimate the conditional logistic regressions, varying the time horizons over which sued firms are included in the sample. Specifically, we experiment with different cut-off dates. For example, the coefficients reported in the first column are obtained after discarding lawsuits that occurred more than a year after the IPO. The second column contains results in which we employ a 2-year benchmark.

The results for the 1-year and 2-year windows yield similar inferences about the CEO equity incentives although the significance level is reduced. Other variables such as the percentage of insiders on the board, CEO age, CEO tenure, the CEO founder dummy, and the leverage ratio remain statistically significant.

Next, we exclude lawsuits that were dismissed, withdrawn or whose outcome is still pending (column 3). Dismissed or withdrawn cases suggest that the judge or the plaintiffs themselves conclude that the events leading to the lawsuit could not contribute to the IPO process. Lowry and Shu (2002) point out that dismissals and withdrawals indicate weak evidence, suggesting that the respective cases should never have been brought in the first place. Pending cases are cases whose final outcome is not yet 
determined. For these reasons, dismissed/withdrawn and pending lawsuits may add noise to the study. When we re-estimate the conditional logistic model 4 in Table 4 after excluding these cases, the results are qualitatively unchanged.

Last, we conduct unconditional logistic regression (model 4) and use white standard errors and covariance (model 5) to re-estimate the model. The results are generally qualitatively unchanged.

\section{Conclusions}

The main purpose of our study is to investigate the relationship between the incidence of IPO-related shareholder litigation and CEO equity incentives on one hand and a series of corporate governance factors on the other hand. We make several contributions to the existing literature. First, our paper is the first study to examine what aspects of an executive's compensation package, his/her personal traits, and the firm's corporate governance mechanisms that are in place prior to the IPO affect the incidence of IPO-related shareholder litigation. Second, our study is the first to explore how the determinants of IPO litigation vary across different types of industries (high-tech vs. nontech) and across different types of allegations (accounting-related vs. non-accounting related cases).

Our empirical analysis employs a sample of 162 sued and non-sued IPO firms (81 matched pairs) and performs a conditional logistic regression to explore the determinants of an IPO firm's litigation risk. Our full sample results indicate that firms in which CEOs have higher equity incentives from pre-IPO options and pre-IPO equity ownership are more likely to face shareholder litigation. We interpret the results as being consistent with 
a "dark side" of incentive compensation, which motivate top executives to commit fraud by artificially inflating the firm's offer price. As such, our results are broadly consistent with Becker's (1968) economic theory of crime. Similar to prior findings for seasoned firms (Denis et al., 2006; Peng and Roell, 2007), salary and bonuses are not significantly related to shareholder litigation. We also find some evidence that firms whose board is dominated by insiders and thus lacks outside monitoring face a higher risk of litigation. In addition, we find that CEO traits including CEO age, CEO tenure, and CEOs being founders are related to the probability of an IPO firm being sued. Specifically, IPO firms led by older CEOs, CEOs with a longer tenure, or CEOs who also founded the firm are more likely to be sued. Finally, we find evidence that suggests that highly leveraged firms are more likely to be sued.

To ensure the robustness of our results, we also perform a test in which we focus on abnormal CEO equity incentives, i.e. incentives beyond the desired level. We find that abnormal equity incentives are significantly positively related to the incidence of shareholder litigation, suggesting that CEOs have "excessive" incentives from pre-IPO options and equity ownership during the IPO process that drive them to perform actions that result in the firm being sued.

Our subsample tests (high tech vs. non-high tech) provide interesting insights into the determinants of litigation risk across different industry sectors. Specifically, we find that the positive association between CEO equity incentives and litigation risk is more pervasive in high tech firms than in non-high tech firms. Furthermore, the deterrence effect of litigation risk hypothesis (Lowry and Shu, 2002) is only supported in the high- 
tech subsample, suggesting that high tech firms tend to underprice their shares more to avoid future litigation. Another subsample test in which we focus on accounting related vs. non-accounting related cases suggest CEO equity incentives are positively related to the incidence of shareholder litigation in both subsamples, indicating that CEO incentives are not only associated with accounting related fraud, but also with non-accounting related fraud.

Finally, our results are robust when we consider different sample periods during which firms are included in the sample and when we exclude dismissed/withdrawn and pending cases.

Although our findings indicate a robust association between CEO equity incentives and fraud allegations, there are two possible explanations for our findings. First, equity incentives might cause top managers to be more likely to engage in fraudulent activity, which leads to higher litigation risk. Second, firms in which CEOs have high equity incentives might be more likely to be sued because they appear to have a financial motive for fraud. We favor the first interpretation as we use private shareholder litigation as a proxy of fraud. However, we do not reject the potential validity of the second explanation. To add some additional insights into this question, future studies in this area could distinguish between firms that were targeted by a parallel SEC enforcement action. Given that the SEC has no financial incentives to prosecute a given firm, SEC actions should allow for a reasonable distinction between merited and unmerited cases. 


\section{References}

Agrawal, A., \& Chadha, S. (2005). Corporate governance and accounting scandals. Journal of Law and Economics, 48(2), 371-406.

Agrawal, A., \& Cooper, T. (2009). Accounting scandals in IPO firms: do underwriters and VCs Help? Working paper. EFA 2008 Athens Meetings Paper; CELS 2009 4th Annual Conference on Empirical Legal Studies.

Alexander, J. C. (1991). Do the merits matter? A study of settlements in securities class actions. Stanford Law Review, 43(3), 497-598.

Balsam, S. (2002). An introduction to executive compensation. San Diego: Academic Press.

Baber, W. R., Kang, S., Liang, L., \& Zhu, Z. (2009). Shareholder rights, corporate governance and accounting restatement. Working paper.

Beasley, M. S. (1996). An empirical analysis of the relation between the board of director composition and financial statement fraud. Accounting Review, 71(4), 443-465.

Becker, G. S. (1968). Crime and punishment: An economic approach. Journal of Political Economy, 76(2), 169-217.

Begley, J., Ming, J., \& Watts, S. (1996). Bankruptcy classification errors in the 1980s: An empirical analysis of Altaian's and Ohlson's models. Review of Accounting Studies, 1(4), 267-284.

Bergstresser, D., \& Philippon, T. (2006). CEO incentives and earnings management. Journal of Financial Economics, 80(3), 511-529.

Bhabra, H. S., \& Pettway, R. H. (2003). IPO prospectus information and subsequent performance. Financial Review, 38(3), 369-397.

Brickley, J. A., Bhagat, S., \& Lease, R. C. (1985). The impact of long-range managerial compensation plans on shareholder wealth. Journal of Accounting and Economics, 7(13), 115-129.

Burns, N., \& Kedia, S. (2006). The impact of performance-based compensation on misreporting. Journal of Financial Economics, 79(1), 35-67.

Carter, R., \& Manaster, S. (1990). Initial public offerings and underwriter reputation. Journal of Finance, 45(4), 1045-1067. 
Certo, S. T., Covin, J. G., Daily, C. M., \& Dalton, D. R. (2001). Wealth and the effects of founder management among IPO-stage new ventures. Strategic Management Journal, 22(6/7), 641-658.

Cheng, Q., \& Warfield, T. D. (2005). Equity incentives and earnings management. Accounting Review, 80(2), 441-476.

Choi, S. J. (2007). Do the merits matter less after the Private Securities Litigation Reform Act? Journal of Law, Economics, and Organization, 23(3), 598-626.

Conyon, M. J., \& Murphy, K. J. (2000). The prince and the pauper? CEO pay in the United States and United Kingdom. The Economic Journal, 110(467), F640-F671.

Crocker, K. J., \& Slemrod, J. (2007). The economics of earnings manipulation and managerial compensation. The Rand Journal of Economics, 38(3), 698-713.

Dechow, P. M., Sloan, R. G., \& Sweeney, A. P. (1996). Causes and consequences of earnings manipulation: An analysis of firms subject to enforcement actions by the SEC. Contemporary Accounting Research, 13(1), 1-36.

Denis, D. J., Hanouna, P., \& Sarin, A. (2006). Is there a dark side to incentive compensation? Journal of Corporate Finance, 12(3), 467-488.

DuCharme, L. L., Malatesta, P. H., \& Sefcik, S. E. (2004). Earnings management, stock issues, and shareholder lawsuits. Journal of Financial Economics, 71(1), 27-49.

Efendi, J., Srivastava, A., \& Swanson, E. P. (2007). Why do corporate managers misstate financial statements? The role of option compensation and other factors. Journal of Financial Economics, 85(3), 667-708.

Erickson, M., Hanlon, M., \& Maydew, E. L. (2006). Is there a link between executive equity incentives and accounting fraud? Journal of Accounting Research, 44(1), 113-143.

Fife, R. W. (1995). How to design a successful pre-IPO stock option program. Compensation and Benefits Review, 27(2), 63.

Frydman, C., \& Saks, R.E. (2007). Executive compensation: A new view from a longterm perspective, 1936-2005, FEDS Working Paper No. 2007-35; AFA 2008 New Orleans Meetings Paper.

Gaver, J. J., Gaver, K. M., \& Austin, J. R. (1995). Additional evidence on bonus plans and income management. Journal of Accounting and Economics, 19(1), 3-28.

Goldman, E., \& Slezak, S. L. (2006). An equilibrium model of incentive contracts in the presence of information manipulation. Journal of Financial Economics, 80(3), 603-626. 
Guidry, F., J. Leone, A., \& Rock, S. (1999). Earnings-based bonus plans and earnings management by business-unit managers. Journal of Accounting and Economics, 26(1-3), 113-142.

Harris, J., \& Bromiley, P. (2007). Incentives to cheat: The influence of executive compensation and firm performance on financial misrepresentation. Organization Science, 18(3), 350-367.

Haugen, R. A., \& Senbet, L. W. (1981). Resolving the agency problems of external capital through options. Journal of Finance, 36(3), 629-647.

Healy, P. M. (1985). The effect of bonus schemes on accounting decisions. Journal of Accounting and Economics, 7(1-3), 85-107.

Hengartner, L. (2006). Explaining executive pay: The roles of managerial power and complexity. Unpublished doctoral dissertation, University of St. Gallen, St. Gallen, Switzerland.

Hermalin, B. E., \& Weisbach, M. S. (1998). Endogenously chosen boards of directors and their monitoring of the CEO. American Economic Review, 88(1), 96-118.

Holthausen, R. W., Larcker, D. F., \& Sloan, R. G. (1995). Annual bonus schemes and the manipulation of earnings. Journal of Accounting and Economics, 19(1), 29-74.

Ibbotson, R. G. (1975). Price performance of common stock new issues. Journal of Financial Economics, 2(3), 235-272.

Jensen, M. C. (1993). The modern industrial revolution, exit, and the failure of internal control systems. Journal of Finance, 48(3), 831-880.

Jensen, M. C., \& Meckling, W. H. (1976). Theory of the firm: Managerial behavior, agency costs and ownership structure. Journal of Financial Economics, 3(4), 305-360.

Jensen, M. C., \& Murphy, K. J. (1990). Performance pay and top-management incentives. Journal of Political Economy, 98(2), 225.

John, T. A., \& John, K. (1993). Top-management compensation and capital structure. Journal of Finance, 48(3), 949-974.

Johnson, M. F., Nelson, K. K., \& Pritchard, A. (2007). Do the merits matter more? The impact of the Private Securities Litigation Reform Act. Journal of Law, Economics, and Organization, 23(3), 627-652.

Johnson, S. A., Ryan, H. E., Jr., \& Tian, Y. S. (2009). Managerial incentives and corporate fraud: The sources of incentives matter. Review of Finance, 13(1), 115-145. 
$\mathrm{Ke}$, B. (2001). Why do CEOs of publicly traded firms prefer reporting small increases in earnings and long duration of consecutive earnings increases? Working Paper, Pennsylvania State University.

Kedia, S., \& Mozumdar, A. (2002). Performance impact of employee stock options. Working paper, Harvard Business School, Boston, MA.

Lambert, R. A., \& Larcker, D. F. (1987). An analysis of the use of accounting and market measures of performance in executive compensation contracts. Journal of Accounting Research, 25, 85-125.

Lewellen, W., Loderer, C., \& Rosenfeld, A. (1985). Merger decisions and executive stock ownership in acquiring firms. Journal of Accounting and Economics, 7(1-3), 209231

Logue, D. E. (1973). On the pricing of unseasoned equity issues: 1965-1969. Journal of Financial and Quantitative Analysis, 8(1), 91-103.

Lowry, M., \& Murphy, K. J. (2007). Executive stock options and IPO underpricing. Journal of Financial Economics, 85(1), 39-65.

Lowry, M., \& Shu, S. (2002). Litigation risk and IPO underpricing. Journal of Financial Economics, 65(3), 309-335.

Mehran, H. (1995). Executive compensation structure, ownership, and firm performance. Journal of Financial Economics, 38(2), 163-184.

Meulbroek, L. K. (2001). The efficiency of equity-linked compensation: Understanding the full cost of awarding executive stock options. Financial Management, 30(2), 5-44.

Michaely, R., \& Shaw, W. H. (1994). The pricing of initial public offerings: tests of adverse-selection and signaling theories. The Review of Financial Studies, 7(2), 279-319.

Murphy, K. J. (1999). Executive compensation. In: Ashenfelter, O., Card, D. (Eds.), Handbook of Labor Economics, (3), North-Holland, Amsterdam, 2485-2563.

Peng, L., \& Roell, A. (2008). Manipulation and equity-based compensation. American Economic Review, 98(2), 285-290.

Peng, L., \& Roell, A. (2008). Executive pay and shareholder litigation. Review of Finance, 12(1), 141-184.

Pukthuanthong, K., Roll, R., \& Walker, T. (2007). How employee stock options and executive equity ownership affect long-term IPO operating performance. Journal of Corporate Finance, 13(5), 695-720. 
Pukthuanthong, K., Turtle, H., \& Walker, T. (2009). Legal opportunism, litigation risk, and IPO underpricing. Working paper, Concordia University.

Ritter, J. R. (1984). The "hot issue" market of 1980. Journal of Business, 57(2), 215-240.

Ritter, J. (1998). Initial public offerings. Contemporary Finance Digest, 2(1), 5-30.

Ronen, J., \& Yaari, V. (2008). Earnings management: Emerging insights in theory, practice, and research. New York, NY: Springer.

Shrieves, R. E., \& Gao, P. (2002). Earnings management and executive compensation: a case of overdose of option and underdose of salary? Working paper, EFA 2002 Meetings, Berlin, Germany.

Tinic, S. M. (1988). Anatomy of initial public offerings of common stock. Journal of Finance, 43(4), 789-822.

Titman, S., \& Wessels, R. (1988). The determinants of capital structure choice. Journal of Finance, 43(1), 1-19.

Wang, Y. (2005). Securities fraud: an economic analysis, Working Paper, University of Maryland.

Weber, M., \& Dudney, D. (2003). A reduced form coefficients analysis of executive ownership, corporate value, and executive compensation. Financial Review, 38(3), 399413.

Yermack, D. (1995). Do corporations award CEO stock options effectively? Journal of Financial Economics, 39(2-3), 237-269. 


\section{Table 1: Sample distribution across years and industries}

The sample consists of 2,268 IPOs between 1997 and 2007 that are provided in the Securities Data Company (SDC) database. Closed-end funds, REITs, financial firms (SIC codes 6000 to 6900), unit offerings, reverse LBOs, spinoffs, ADRs, and foreign issues are excluded. Sued firms are identified through Stanford University's Securities Class Action Clearinghouse (http://securities.stanford.edu) and the Securities Class Action Alert (SCAA). Laddering cases filed against the underwriters in which issuers are named as codefendants are excluded from our sample. Panel A classifies the total number of IPOs and the number of IPOs that were sued by year. Panel B classifies the firms by industry where industries are identified based on SIC codes.

Panel A : Number of IPOs (1997-2007) sued

\begin{tabular}{cccc}
\hline IPO year & $\begin{array}{c}\text { Number of IPOs } \\
\text { sued under } \\
\text { Section 11 }\end{array}$ & No. of IPOs & $\begin{array}{c}\text { \% of IPOs sued under } \\
\text { Section 11 }\end{array}$ \\
\hline 1997 & 14 & 477 & 2.94 \\
1998 & 11 & 259 & 4.25 \\
1999 & 11 & 413 & 2.66 \\
2000 & 11 & 331 & 3.32 \\
2001 & 2 & 61 & 3.28 \\
2002 & 2 & 55 & 3.64 \\
2003 & 1 & 54 & 1.85 \\
2004 & 7 & 158 & 4.43 \\
2005 & 6 & 148 & 4.05 \\
2006 & 6 & 152 & 3.95 \\
2007 & 10 & 160 & 6.25 \\
\hline Total & $\mathbf{8 1}$ & $\mathbf{2 , 2 6 8}$ & 3.57 \\
\hline
\end{tabular}


Table 1 (continued)

\begin{tabular}{|c|c|c|c|c|}
\hline Industry & SIC codes & No. of IPOs & $\begin{array}{l}\text { Number of IPOs } \\
\text { sued under } \\
\text { Section } 11 \\
\end{array}$ & $\begin{array}{l}\text { \% of IPOs } \\
\text { sued under } \\
\text { Section } 11\end{array}$ \\
\hline Agriculture and mining & $100-1299,1400-1499$ & 15 & 0 & 0.0 \\
\hline Apparel & 2200-2399,3100-3199 & 18 & 3 & 16.7 \\
\hline $\begin{array}{l}\text { Communications, computers, } \\
\text { and electronics }\end{array}$ & $\begin{array}{l}3570-3579,3600-3699,4800- \\
4899,7370-7379\end{array}$ & 979 & 47 & 4.8 \\
\hline Construction & $1500-1799$ & 19 & 0 & 0.0 \\
\hline Food & $2000-2099$ & 33 & 0 & 0.0 \\
\hline Health & 8000-8099 & 49 & 3 & 6.1 \\
\hline Manufacturing & $\begin{array}{l}2400-2499,2600-2699,2800- \\
2899,3000-3099,3200- \\
3569,3580-3599,3900-3999\end{array}$ & 318 & 11 & 3.5 \\
\hline Oil and gas & $\begin{array}{l}1300-1399,2900-2999,4600- \\
4699,4920-4929\end{array}$ & 93 & 2 & 2.2 \\
\hline Printing and publishing & $2700-2799$ & 17 & 0 & 0.0 \\
\hline Recreation & 7000-7099,7800-7999 & 38 & 0 & 0.0 \\
\hline Science & $\begin{array}{l}3800-3899,8710-8719,8730- \\
8739\end{array}$ & 181 & 3 & 1.7 \\
\hline services & $\begin{array}{l}7200-7369,7380-7399,7600- \\
7699,8100-8399,8720- \\
8729,8740-8749\end{array}$ & 188 & 2 & 1.1 \\
\hline Trade & $5000-5999$ & 196 & 7 & 3.6 \\
\hline Transportation & $\begin{array}{l}3700-3799,4000-4299,4400- \\
4599,4700-4799,7510-7549\end{array}$ & 104 & 2 & 1.9 \\
\hline Utilities & $4910-4919,4930-4979$ & 20 & 1 & 5.0 \\
\hline Total & & 2,268 & 81 & 3.6 \\
\hline
\end{tabular}




\section{Table 2 (continued)}

\section{Table 2: Nature, resolution, and timing of lawsuits}

This table provides summary statistics for our IPO litigation sample. In Panel A, we identify the nature of lawsuits by carefully reading the case summary for each lawsuit in our sample as provided by Stanford University's Securities Class Action Clearinghouse (SCAC) (http://securities.stanford.edu). Because some lawsuits involve multiple allegations, the number of allegations (88) exceeds the number of lawsuits (81) in our sample. Panel B provides information on the resolution of lawsuits. We search the SCAC, the Securities Class Action Alert (SCAA) and the Department of Justice Public Access to Court Electronic Records (PACER) (http://pacer.psc.uscourts.gov) database to determine how each lawsuit was resolved. Panel $C$ reports information on the timing of lawsuits. Specifically, we obtain the length of the class period, the time between the lawsuit filing date and the IPO date and the time between the lawsuit filing date and the ending date of the class period. Finally, Panel $D$ categorizes the litigation sample based on the length of time between the IPO date and lawsuit filing date.

Panel A: Nature of allegations

\begin{tabular}{lcc}
\hline Nature of legal claim & Number of cases & Percentage of total \\
\hline $\begin{array}{l}\text { Failure to disclose material adverse } \\
\text { information/known risks and Overoptimistic } \\
\text { forecasts }\end{array}$ & 32 & 39.5 \\
Failure to disclose existing business problems & 19 & 23.5 \\
Misrepresentations about financial condition & 6 & 7.4 \\
$\begin{array}{l}\text { Revenue management / Expense management } \\
\text { / Earnings management }\end{array}$ & 14 & 17.3 \\
$\begin{array}{l}\text { Improper Accounting Practices / Violations of } \\
\text { GAAP }\end{array}$ & 12 & 14.8 \\
Others & 5 & 6.2 \\
\hline Total & 88 & 108.6 \\
\hline
\end{tabular}

Panel B: Outcome of the lawsuits

Settled $\quad \frac{\text { Number of cases }}{43}$

Dismissed/withdrawn 
Panel C: Timing of lawsuits

\begin{tabular}{lccccccc}
\hline & Mean & Minimum & Quartile 1 & Median & Quartile 3 & Maximum & Std Dev \\
\hline $\begin{array}{l}\text { Length of the class action } \\
\text { period (days) }\end{array}$ & 229 & 0 & 80 & 173 & 293 & 1,164 & 223 \\
$\begin{array}{l}\text { Length of time between the } \\
\text { lawsuit filing date and the }\end{array}$ & 321 & 5 & 116 & 274 & 444 & 1,172 & 254 \\
$\begin{array}{l}\text { IPO date (days) } \\
\text { Length of time between the }\end{array}$ & 94 & 0 & 5 & 25 & 159 & 535 & 128 \\
$\begin{array}{l}\text { lawsuit filing date and the } \\
\text { end of the class action } \\
\text { period (days) }\end{array}$ & 94 & & & & & & \\
\hline
\end{tabular}

Panel D: Distribution of lawsuits by time to filing

\begin{tabular}{cc}
$\begin{array}{c}\text { No. of lawsuits filed } \\
\text { within } 1,2 \text { or } 3 \text { years after the IPO }\end{array}$ & $\begin{array}{c}\text { Number of } \\
\text { cases }\end{array}$ \\
\cline { 2 - 2 } $1^{\text {st }}$ year & 50 \\
$2^{\text {nd }}$ Year & 25 \\
$3^{\text {nd }}$ Year & 6 \\
\hline Total & 81 \\
\hline
\end{tabular}


Table 3: Characteristics of sued vs. non-sued firms

The sample consists of 81 IPO firms (issued between 1997 and 2007) that were subsequently sued in connection with their offering. The control group consists of 81 firms that were matched with the sample firms based on size, year and industry. Compensation and ownership data as well as boards and CEO traits are obtained from IPO prospectuses and proxy statements. IPO characteristics are obtained from SDC but are cross-referenced with each firm's IPO prospectus. In case of discrepancies between SDC data entries and IPO prospectus information, the latter data are used. Firm characteristics are obtained from Compustat. Information on Stock prices (used to calculate the initial returns) is obtained from the Center for Research in Securities Price (CRSP) database. Definitions for all variables are given in Appendix 1. All dollar values are based on inflation-adjusted 2007 dollars. In Panel A, we compare the compensation and ownership characteristics of the CEOs in our two subsamples of sued and non-sued firms. In Panels $B$ and $C$, we compare the offering and firm characteristics of the IPOs in each subsample. In Panel D, we compare the board characteristics and CEO traits among the two subsamples. The first column labels our variables. In columns 2 and 3 (columns 4 and 5), we present information on the mean and median variable values for sued (non-sued) firms, respectively. in the last two columns, we present $p$-value for a t-test and Wilcoxon test for the difference in mean and median values between our two subsamples. Significant differences are highlighted in italics.

\begin{tabular}{|c|c|c|c|c|c|c|}
\hline \multirow[t]{2}{*}{ Variables } & \multicolumn{2}{|c|}{ Sued IPO firms } & \multicolumn{2}{|c|}{$\begin{array}{l}\text { Non-sued } \\
\text { IPO firms } \\
\end{array}$} & \multicolumn{2}{|c|}{$\begin{array}{l}\text { P-Value of pairwise } \\
\text { difference }\end{array}$} \\
\hline & Mean & Median & Mean & Median & T-test & Wilcoxon test \\
\hline \multicolumn{7}{|c|}{ Panel A : Compensation and ownership characteristics } \\
\hline $\begin{array}{l}\text { Pre-IPO options (\% } \\
\text { scaled by pre-IPO } \\
\text { shares outstanding) }\end{array}$ & 2.53 & 1.11 & 2.10 & 1.03 & $(0.427)$ & $(0.780)$ \\
\hline $\begin{array}{l}\text { Pre-IPO ownership (\% } \\
\text { scaled by pre-IPO } \\
\text { shares outstanding) }\end{array}$ & 18.05 & 5.23 & 12.07 & 5.49 & $(0.036)$ & $(0.165)$ \\
\hline Bonus ( $\$$ thousand) & 90 & 25 & 122 & 43 & $(0.308)$ & $(0.477)$ \\
\hline Salary ( $\$$ thousand) & 262 & 227 & 219 & 205 & $(0.016)$ & (0.029) \\
\hline $\begin{array}{l}\text { Ex-ante gain from a } \\
\text { dollar increase in the } \\
\text { offer price ( } \$ \text { million) }\end{array}$ & 4.41 & 1.84 & 2.51 & 1.43 & $(0.036)$ & $(0.115)$ \\
\hline $\begin{array}{l}\text { IPO options to CEO } \\
\text { dummy }\end{array}$ & 0.20 & 0.00 & 0.27 & 0.00 & $(0.276)$ & $(0.281)$ \\
\hline \multicolumn{7}{|c|}{ Panel B: IPO characteristics } \\
\hline Price per share (\$) & 14.05 & 14.00 & 12.55 & 13.00 & $(0.047)$ & $(0.014)$ \\
\hline Offer size (\$ million) & 105.90 & 76.90 & 79.51 & 58.80 & (0.027) & $(0.003)$ \\
\hline Initial return & $34.68 \%$ & $13.54 \%$ & $34.64 \%$ & $13.41 \%$ & $(0.955)$ & $(0.642)$ \\
\hline $\begin{array}{l}\text { High quality auditor } \\
\text { dummy }\end{array}$ & 0.88 & 1.00 & 0.95 & 1.00 & $(0.109)$ & $(0.180)$ \\
\hline
\end{tabular}




\begin{tabular}{|c|c|c|c|c|c|c|}
\hline \multicolumn{7}{|l|}{ Panel B (continued) } \\
\hline VC- backed dummy & 0.59 & 1.00 & 0.64 & 1.00 & $(0.453)$ & $(0.460)$ \\
\hline Underwriter rank & 7.96 & 8.50 & 7.72 & 9.00 & $(0.313)$ & $(0.570)$ \\
\hline $\begin{array}{l}\text { Proportion of firms } \\
\text { listed on the Nasdaq }\end{array}$ & 0.83 & 1.00 & 0.91 & 1.00 & $(0.109)$ & $(0.167)$ \\
\hline \multicolumn{7}{|c|}{ Panel C: Firm characteristics } \\
\hline Total assets ( $\$$ million) & 133.75 & 37.26 & 100.62 & 36.93 & $(0.280)$ & $(0.764)$ \\
\hline Sales ( $\$$ million) & 100.80 & 33.64 & 82.75 & 29.96 & (0.329) & $(0.143)$ \\
\hline Firm Age (years) & 9.5 & 7.0 & 10.5 & 7.0 & $(0.366)$ & $(0.647)$ \\
\hline OIBD/TA (\%) & -18.02 & -0.22 & -27.26 & 2.98 & $(0.872)$ & $(0.947)$ \\
\hline TD/TA (\%) & 32.48 & 22.52 & 23.74 & 14.86 & $(0.083)$ & $(0.198)$ \\
\hline R\&D/TA (\%) & 20.46 & 5.70 & 18.33 & 9.92 & $(0.762)$ & $(0.570)$ \\
\hline PPE/TA (\%) & 21.93 & 14.42 & 19.16 & 13.52 & $(0.288)$ & (0.562) \\
\hline \multicolumn{7}{|c|}{ Panel D: Board and CEO traits } \\
\hline $\begin{array}{l}\text { Proportion of firms in } \\
\text { which the CEO chairs } \\
\text { the board }\end{array}$ & 0.51 & 1.00 & 0.53 & 1.00 & $(0.754)$ & $(0.875)$ \\
\hline $\begin{array}{l}\text { Proportion of firms } \\
\text { with inside directors }\end{array}$ & 0.32 & 0.29 & 0.27 & 0.25 & (0.023) & $(0.054)$ \\
\hline $\begin{array}{l}\text { Proportion of firms } \\
\text { with founder CEOs }\end{array}$ & 0.41 & 0.00 & 0.37 & 0.00 & $(0.615)$ & (0.619) \\
\hline Board size & 6.59 & 6.00 & 6.9 & 7.0 & $(0.200)$ & (0.178) \\
\hline CEO age & 48 & 48 & 46 & 46 & $(0.142)$ & $(0.112)$ \\
\hline CEO tenure & 4.5 & 3.0 & 5.3 & 4.0 & $(0.280)$ & (0.326) \\
\hline
\end{tabular}




\section{Table 4: Conditional matched-pair logistic regression}

We perform a conditional matched-pair logistic regression to predict an IPO firm's likelihood of being named in a prospectus liability case. The dependent variable is one if the firm is the target of an IPO-related securities class action lawsuit and zero otherwise. Our main incentive measures are measured as the number of pre-IPO shares or options held by a CEO deflated by the number of pre-IPO shares outstanding. The ex-ante gain from inflating the offer price equals the number of shares held by the CEO, plus the number of pre-IPO options owned by the CEO, in millions. Our sued-firm sample consists of 81 IPO firms (issued between 1997 and 2007) that were the target of a prospectus liability case. The control group consists of $\mathbf{8 1}$ firms that were matched with our sample firms based on size, industry, and IPO year. Definitions for all variables are given in Appendix 1. Missing data on certain explanatory variables limit the sample size in some regressions. The predicted signs for each regressor are provided in parentheses besides the variable names. One-tailed test is applied for directional hypotheses. To denote statistical significance, we use *** for the $1 \%$ level, ** for the $5 \%$ level, and * for the $10 \%$ level.

\begin{tabular}{|c|c|c|c|c|c|c|}
\hline & Model 1 & Model 2 & Model 3 & Model 4 & Model 5 & Model 6 \\
\hline \multirow[t]{2}{*}{ Aggregate equity incentives $(+)$} & $3.874^{* *}$ & $3.788^{* *}$ & & & & \\
\hline & $(0.021)$ & $(0.018)$ & & & & \\
\hline \multirow[t]{2}{*}{ Incentives from pre-IPO options (t) } & & & $23.840^{* *}$ & $21.136^{* *}$ & & \\
\hline & & & $(0.017)$ & $(0.019)$ & & \\
\hline \multirow[t]{2}{*}{ Incentives from equity ownership (+) } & & & $3.185^{* *}$ & $3.280^{* *}$ & & \\
\hline & & & $(0.043)$ & $(0.033)$ & & \\
\hline \multirow[t]{2}{*}{ Ex-ante gain (t) } & & & & & $1.172^{* *}$ & $1.222^{* *}$ \\
\hline & & & & & $(0.050)$ & $(0.034)$ \\
\hline \multirow[t]{2}{*}{$\operatorname{Ln}(1+$ salary $)(?)$} & -0.135 & -0.159 & -0.129 & -0.119 & & \\
\hline & $(0.513)$ & $(0.431)$ & $(0.522)$ & $(0.534)$ & & \\
\hline \multirow[t]{2}{*}{$\operatorname{Ln}(1+$ bonus $)(?)$} & -0.041 & -0.038 & -0.087 & -0.073 & & \\
\hline & $(0.351)$ & $(0.354)$ & $(0.107)$ & $(0.127)$ & & \\
\hline \multirow[t]{2}{*}{$\%$ Insiders on the board $(+)$} & 1.344 & $1.838^{*}$ & 2.181 & $2.480^{*}$ & $2.222^{*}$ & $2.546^{* *}$ \\
\hline & $(0.251)$ & $(0.091)$ & $(0.147)$ & $(0.065)$ & $(0.090)$ & $(0.040)$ \\
\hline \multirow[t]{2}{*}{ CEO chairman dummy (?) } & -0.204 & -0.237 & -0.152 & -0.175 & -0.135 & -0.160 \\
\hline & $(0.672)$ & $\{0.575\}$ & $(0.760)$ & $(0.692)$ & $(0.758)$ & (0.692) \\
\hline \multirow[t]{2}{*}{ IPO option dummy (?) } & -0.268 & & -0.034 & & -0.2886 & \\
\hline & $(0.681)$ & & $(0.961)$ & & $(0.616)$ & \\
\hline \multirow[t]{2}{*}{ Auditor quality dummy (?) } & -0.647 & & -0.882 & & -0.697 & \\
\hline & $(0.472)$ & & $(0.347)$ & & $(0.407)$ & \\
\hline \multirow[t]{2}{*}{ Underwriter rank (?) } & 0.368 & $0.348 * *$ & 0.394 & $0.337^{*}$ & 0.249 & 0.242 \\
\hline & $(0.133)$ & $(0.044)$ & $(0.150)$ & $(0.073)$ & $(0.24)$ & $(0.113)$ \\
\hline \multirow[t]{2}{*}{ Offer size (+) } & 0.004 & $0.004^{*}$ & $0.006^{*}$ & $0.005^{*}$ & 0.003 & 0.003 \\
\hline & $(0.136)$ & $(0.092)$ & $(0.096)$ & $(0.061)$ & $(0.198)$ & $(0.132)$ \\
\hline
\end{tabular}




\begin{tabular}{|c|c|c|c|c|c|c|}
\hline \multirow[t]{2}{*}{ VC- backed dummy (?) } & 0.170 & & 0.545 & & 0.160 & \\
\hline & $(0.790)$ & & $(0.429)$ & & $(0.778)$ & \\
\hline \multirow[t]{2}{*}{ Underpricing (?) } & 0.120 & & 0.103 & & 0.074 & \\
\hline & $(0.782)$ & & $(0.823)$ & & $(0.856)$ & \\
\hline \multirow[t]{2}{*}{ Ln(Assets) (?) } & 0.199 & 0.198 & 0.284 & 0.355 & 0.016 & -0.001 \\
\hline & $(0.637)$ & $(0.614)$ & $(0.541)$ & $(0.439)$ & (0.967) & $(0.997)$ \\
\hline \multirow[t]{2}{*}{ OIBD/TA (?) } & 0.501 & & 0.532 & & 0.432 & \\
\hline & $(0.638)$ & & (0.634) & & $(0.648)$ & \\
\hline \multirow[t]{2}{*}{$\mathrm{TD} / \mathrm{TA}(+)$} & $1.580^{*}$ & $1.286^{*}$ & $1.8552^{* *}$ & $1.436^{*}$ & 1.084 & 0.953 \\
\hline & $(0.079)$ & $(0.081)$ & $(0.050)$ & $(0.065)$ & (0.112) & $(0.109)$ \\
\hline \multirow[t]{2}{*}{ PPE/TA (?) } & -0.280 & & 0.235 & & 0.474 & \\
\hline & (0.859) & & (0.888) & & $(0.744)$ & \\
\hline \multirow[t]{2}{*}{$R \& D / T A(?)$} & 1.133 & & 1.095 & & 0.773 & \\
\hline & $(0.495)$ & & $(0.568)$ & & $(0.564)$ & \\
\hline \multirow[t]{2}{*}{$\operatorname{Ln}(1+$ firm age $)(?)$} & -0.110 & & 0.066 & & -0.158 & \\
\hline & $(0.813)$ & & $(0.897)$ & & $(0.717)$ & \\
\hline \multirow[t]{2}{*}{$\operatorname{Ln}($ CEO age) $(+)$} & $4.001^{* *}$ & $3.906^{* * *}$ & $4.701 * * *$ & $4.340^{* * *}$ & $3.506^{* *}$ & $3.589^{* * *}$ \\
\hline & $(0.015)$ & $(0.010)$ & $(0.008)$ & $(0.007)$ & $(0.013)$ & $(0.006)$ \\
\hline \multirow[t]{2}{*}{$\operatorname{Ln}(1+$ CEO tenure $)(?)$} & $-0.928^{* *}$ & $-0.886^{* *}$ & $-1.176^{* * *}$ & $-1.111^{* * *}$ & $-0.701^{*}$ & $-0.698^{* *}$ \\
\hline & $(0.023)$ & $(0.018)$ & $(0.008)$ & $(0.008)$ & $(0.053)$ & $(0.037)$ \\
\hline \multirow[t]{2}{*}{ CEO founder dummy $(+)$} & $0.934^{*}$ & $1.030^{* *}$ & $1.320^{* *}$ & $1.299 * *$ & $0.961^{*}$ & $0.985^{* *}$ \\
\hline & $(0.086)$ & $(0.044)$ & $(0.042)$ & $(0.024)$ & $(0.060)$ & $(0.040)$ \\
\hline \multirow[t]{2}{*}{ Exchange dummy (?) } & 0.238 & & 0.300 & & -0.104 & \\
\hline & $(0.807)$ & & $(0.770)$ & & $(0.902)$ & \\
\hline Observations & 156 & 158 & 156 & 158 & 156 & 158 \\
\hline Model chi-square & 31.42 & 30.66 & 35.64 & 34.57 & 25.64 & 24.71 \\
\hline$p$-value & 0.088 & 0.002 & 0.045 & 0.001 & 0.141 & 0.006 \\
\hline Pseudo $\mathrm{R}^{2}$ & $18.15 \%$ & $17.64 \%$ & $20.31 \%$ & $19.65 \%$ & $15.07 \%$ & $14.48 \%$ \\
\hline
\end{tabular}




\section{Table 5: Conditional matched-pair logistic regression (abnormal incentives)}

We perform a conditional matched-pair logistic regression to predict an IPO firm's likelihood of being named in a prospectus liability case. The dependent variable is one if the firm is the target of an IPO-related securities class action lawsuit and zero otherwise. Abnormal incentives are incentives that are beyond the desired level that can be explained by other factors. We regress the equity incentives and cash compensation on CEO age, CEO tenure, company age, board size, a founder dummy, a CEO chair dummy, as well as the firm's total assets, R\&D, leverage, tangibility, profitability and a VC-backed dummy. The residuals (abnormal incentives) from the first-stage models are then included as independent variables in the corresponding second-stage models. The sample consists of 81 IPO firms (issued between 1997 and 2007) that were the target of a prospectus liability case. The control group consists of 81 firms that were matched with sample firms on size, industry, and IPO year. Definitions for all variables are given in Appendix 1. Missing data on certain explanatory variables limit the sample size in some regressions. The predicted signs for each regressor are provided in parentheses besides the variable names. One-tailed test is applied for directional hypotheses. To denote statistical significance, we use ${ }^{* * *}$ for the $1 \%$ level, ${ }^{* *}$ for the $5 \%$ level, and * for the $10 \%$ level.

\begin{tabular}{|c|c|c|c|}
\hline & Model 1 & Model 2 & Model 3 \\
\hline \multirow[t]{2}{*}{ Abnormal aggregate equity incentives $(+)$} & $3.832^{* *}$ & & \\
\hline & $(0.016)$ & & \\
\hline \multirow[t]{2}{*}{ Abnormal incentives from pre-IPO options (+) } & & $18.938^{* *}$ & \\
\hline & & $(0.026)$ & \\
\hline \multirow[t]{2}{*}{ Abnormal incentives from equity ownership (+) } & & $3.267^{* *}$ & \\
\hline & & $(0.033)$ & \\
\hline \multirow[t]{2}{*}{ Abnormal incentives from ex-ante gain (+) } & & & $1.214^{* *}$ \\
\hline & & & $(0.036)$ \\
\hline \multirow[t]{2}{*}{$\operatorname{Ln}(1+$ salary) (residual) (?) } & -0.155 & -0.138 & \\
\hline & $(0.464)$ & $(0.513)$ & \\
\hline \multirow[t]{2}{*}{ Ln(1+bonus) (residual) (?) } & -0.030 & -0.065 & \\
\hline & $(0.474)$ & $(0.188)$ & \\
\hline \multirow[t]{2}{*}{$\%$ insiders on the board (+) } & $2.056^{*}$ & $2.554^{*}$ & $2.290^{*}$ \\
\hline & $(0.088)$ & $(0.058)$ & $(0.061)$ \\
\hline \multirow[t]{2}{*}{ CEO chairman dummy (?) } & 0.111 & 0.073 & -0.041 \\
\hline & (0.798) & $(0.872)$ & $(0.920)$ \\
\hline \multirow[t]{2}{*}{ Underwriter rank (?) } & $0.306^{*}$ & $0.314^{*}$ & 0.245 \\
\hline & $(0.078)$ & $(0.097)$ & $(0.109)$ \\
\hline \multirow[t]{2}{*}{ Offer size (+) } & 0.004 & $0.005^{*}$ & 0.003 \\
\hline & $(0.127)$ & $(0.097)$ & $(0.165)$ \\
\hline \multirow[t]{2}{*}{ Underpricing (?) } & 0.237 & 0.247 & 0.145 \\
\hline & $(0.546)$ & $(0.54)$ & $\{0.688\}$ \\
\hline \multirow[t]{2}{*}{ Ln(Assets) (?) } & 0.078 & 0.228 & 0.071 \\
\hline & $(0.848)$ & $(0.632)$ & $(0.850)$ \\
\hline \multirow[t]{2}{*}{$\ln ($ CEO age $)(+)$} & $4.012^{* *}$ & $3.984^{* *}$ & $3.609 * * *$ \\
\hline & $(0.011)$ & $(0.013)$ & $(0.007)$ \\
\hline \multirow[t]{2}{*}{$\operatorname{Ln}(1+$ CEO tenure $)(?)$} & $-0.908^{* *}$ & $-1.049^{* * *}$ & $-0.783^{* *}$ \\
\hline & $(0.015)$ & $(0.008)$ & $(0.028)$ \\
\hline \multirow[t]{2}{*}{ CEO founder dummy $(+)$} & $1.627^{* * *}$ & $1.729 * * *$ & $1.281^{* *}$ \\
\hline & $(0.009)$ & $(0.008)$ & $(0.017)$ \\
\hline \multirow[t]{2}{*}{ TD/TA (+) } & $1.343^{*}$ & $1.371^{*}$ & 0.907 \\
\hline & $(0.081)$ & $(0.081)$ & $(0.137)$ \\
\hline \multirow[t]{2}{*}{ Exchange dummy (?) } & 0.061 & 0.140 & 0.038 \\
\hline & $(0.943)$ & $(0.874)$ & $(0.959)$ \\
\hline Observations & 156 & 156 & 156 \\
\hline Model chi-square & 25.94 & 33.03 & 24.13 \\
\hline p-value & 0.026 & 0.005 & 0.020 \\
\hline Pseudo $\mathrm{R}^{2}$ & $15.23 \%$ & $18.97 \%$ & $14.25 \%$ \\
\hline
\end{tabular}


Table 6: Conditional matched-pair logistic regression

(high tech firms vs. non-high tech firms)

We perform a conditional matched-pair logistic regression to predict an IPO firm's likelihood of being named in a prospectus liability case. The dependent variable is one if the firm is the target of an IPO-related securities class action lawsuit and zero otherwise. The main sample is partitioned into two groups: sued high tech firms and sued non-high tech firms. (We distinguish between high-tech and non-tech firms following the classification by American Electronics Association). For each subsample, we re-estimate the same models we employed in Table 4. Due to the previous matching criteria and missing data for certain explanatory variables, we get our high tech firms subsample including 31 sued and non-sued firms and non-high firms including 30 sued and non-sued firms. Definitions for all variables are given in Appendix 1. The predicted signs for each regressor are provided in parentheses besides the variable names. One-tailed test is applied for directional hypotheses. To denote statistical significance, we use *** for the $1 \%$ level, ** for the $5 \%$ level, and * for the $10 \%$ level.

\begin{tabular}{|c|c|c|c|c|c|c|}
\hline & \multicolumn{3}{|c|}{ High tech firms } & \multicolumn{3}{|c|}{ Non-high tech firms } \\
\hline & Model 1 & Model 2 & Model 3 & Model 4 & Model 5 & Model 6 \\
\hline \multirow[t]{2}{*}{ Aggregate equity incentives $(+)$} & $15.725^{* *}$ & & & 1.317 & & \\
\hline & $(0.018)$ & & & $(0.300)$ & & \\
\hline \multirow[t]{2}{*}{ Incentives from pre-IPO options (+) } & & 40.009 & & & 14.846 & \\
\hline & & $(0.106)$ & & & $(0.196)$ & \\
\hline \multirow[t]{2}{*}{ Incentives from equity ownership (+) } & & $13.319 * *$ & & & 1.309 & \\
\hline & & $(0.030)$ & & & (0.299) & \\
\hline \multirow[t]{2}{*}{ Incentives from ex-ante gain (+) } & & & $2.699^{*}$ & & & 0.990 \\
\hline & & & $(0.090)$ & & & $(0.253)$ \\
\hline \multirow[t]{2}{*}{$\operatorname{Ln}(1+$ bonus) (?) } & -0.149 & -0.202 & -0.066 & -0.042 & -0.060 & -0.042 \\
\hline & $(0.186)$ & $(0.135)$ & $(0.482)$ & $(0.529)$ & $(0.417)$ & $(0.524)$ \\
\hline \multirow[t]{2}{*}{$\%$ Insiders on the board (+) } & 0.944 & 2.378 & $5.157^{*}$ & 2.730 & 2.576 & 2.938 \\
\hline & (0.395) & $(0.273)$ & $(0.072)$ & $(0.181)$ & $\langle 0.200\rangle$ & $(0.149)$ \\
\hline \multirow[t]{2}{*}{ Underwriter rank (?) } & 0.684 & 0.797 & 0.435 & 0.256 & 0.199 & 0.227 \\
\hline & $(0.137)$ & $(0.130)$ & $(0.270)$ & $(0.255)$ & $(0.388)$ & $(0.317)$ \\
\hline \multirow[t]{2}{*}{ VC- backed dummy (?) } & $-3.792^{*}$ & -3.031 & -1.312 & 0.016 & 0.103 & 0.090 \\
\hline & $(0.061)$ & $(0.132)$ & $(0.252)$ & $(0.987)$ & $(0.914)$ & $(0.925)$ \\
\hline \multirow[t]{2}{*}{ Underpricing (?) } & $-2.709^{*}$ & $-2.739 *$ & -1.740 & 0.392 & 0.206 & 0.166 \\
\hline & $(0.099)$ & $(0.093)$ & $(0.205)$ & $(0.735)$ & $(0.857)$ & (0.891) \\
\hline \multirow[t]{2}{*}{ Ln(Assets) (?) } & -0.269 & 0.553 & -0.044 & -0.029 & 0.099 & -0.123 \\
\hline & $(0.785)$ & $(0.691)$ & $(0.961)$ & $(0.956)$ & $(0.858)$ & $(0.826)$ \\
\hline \multirow[t]{2}{*}{$\operatorname{Ln}(C E O$ age $)(+)$} & $7.564^{* *}$ & $7.704^{* *}$ & $5.492^{*}$ & $5.627^{*}$ & $5.767^{* *}$ & $5.681^{*}$ \\
\hline & $(0.030)$ & $(0.034)$ & $(0.059)$ & $(0.056)$ & $(0.050)$ & $(0.051)$ \\
\hline \multirow[t]{2}{*}{$\operatorname{Ln}(1+$ CEO tenure) (?) } & $-4.267^{* *}$ & $-4.127^{* *}$ & $-1.978^{*}$ & 0.107 & -0.030 & 0.200 \\
\hline & $(0.039)$ & $(0.034)$ & $(0.072)$ & $(0.867)$ & $(0.963)$ & $(0.701)$ \\
\hline \multirow[t]{2}{*}{ CEO founder dummy (t) } & 0.087 & 0.918 & 1.032 & 0.622 & 0.682 & 0.593 \\
\hline & $(0.472)$ & (0.299) & $(0.190)$ & $(0.254)$ & $(0.232)$ & $(0.258)$ \\
\hline \multirow[t]{2}{*}{ TD/TA (+) } & $2.128^{*}$ & $2.339^{*}$ & 1.363 & 0.066 & 0.220 & -0.109 \\
\hline & $(0.064)$ & $(0.065)$ & $(0.132)$ & $(0.483)$ & $(0.446)$ & $(0.471)$ \\
\hline Observations & 62 & 62 & 62 & 60 & 60 & 60 \\
\hline Model chi-square & 18.48 & 19.29 & 14.80 & 19.24 & 20.81 & 19.44 \\
\hline$p$-value & 0.071 & 0.082 & 0.192 & 0.057 & 0.053 & 0.054 \\
\hline Pseudo $\mathrm{R}^{2}$ & $25.42 \%$ & $26.38 \%$ & $20.93 \%$ & $26.32 \%$ & $28.13 \%$ & $26.55 \%$ \\
\hline
\end{tabular}


Table 7: Conditional matched-pair logistic regression

(accounting related litigation vs. non-accounting related litigation)

We perform a conditional matched-pair logistic regression to predict an IPO firm's likelihood of being named in a prospectus liability case. The dependent variable is one if the firm is the target of an IPO-related securities class action lawsuit and zero otherwise. The main sample is partitioned into two groups: accounting related lawsuits and non-accounting related lawsuits. We then re-estimate the same models we employed in Table 4 . Model 1 to 3 are based on a sample of 21 sued firms with accounting-related cases and their control firms, while models 4 to 6 employ a sample of 55 sued firms with non-accounting related cases and their control firms. Five sued firms and their non-sued counterparts are excluded due to missing information on some of our explanatory variables. Definitions for all variables are given in Appendix 1 . The predicted signs for each regressor are provided in parentheses besides the variable names. One-tailed test is applied for directional hypotheses. To denote statistical significance, we use *** for the $1 \%$ level, ${ }^{* *}$ for the $5 \%$ level, and * for the $10 \%$ level.

\begin{tabular}{|c|c|c|c|c|c|c|}
\hline & \multicolumn{3}{|c|}{ Accounting related litigation } & \multicolumn{3}{|c|}{ Non-accounting related litigation } \\
\hline & Model 1 & Model 2 & Model 3 & Model 4 & Model 5 & Model 6 \\
\hline \multirow[t]{2}{*}{ Aggregate equity incentives (+) } & $9.118^{*}$ & & & $2.369^{*}$ & & \\
\hline & $(0.054)$ & & & $(0.074)$ & & \\
\hline \multirow[t]{2}{*}{ Incentives from pre-IPO options (+) } & & 16.531 & & & 11.757 & \\
\hline & & $(0.324)$ & & & $(0.111)$ & \\
\hline \multirow[t]{2}{*}{ Incentives from equity ownership (+) } & & $8.424^{*}$ & & & $2.161^{*}$ & \\
\hline & & $(0.078)$ & & & $(0.097)$ & \\
\hline \multirow[t]{2}{*}{ Incentives from ex-ante gain $(+)$} & & & $1.828^{*}$ & & & 1.058 \\
\hline & & & $(0.071)$ & & & $(0.167)$ \\
\hline \multirow[t]{2}{*}{$\operatorname{Ln}(1+$ bonus) (?) } & -0.201 & -0.202 & -0.170 & -0.028 & -0.051 & -0.033 \\
\hline & $(0.140)$ & $(0.136)$ & $(0.203)$ & $(0.590)$ & $(0.385)$ & $(0.514)$ \\
\hline \multirow[t]{2}{*}{$\%$ Insiders on the board (+) } & -3.055 & -2.476 & -2.027 & $2.520^{*}$ & $3.041^{*}$ & $3.186^{* *}$ \\
\hline & $(0.338)$ & $(0.373)$ & $(0.381)$ & $(0.081)$ & $(0.055)$ & $(0.035)$ \\
\hline \multirow[t]{2}{*}{ Underwriter rank (?) } & 0.723 & 0.710 & 0.503 & $0.377^{*}$ & $0.378^{*}$ & $0.340^{*}$ \\
\hline & $(0.197)$ & $(0.209)$ & $(0.325)$ & $(0.061)$ & $(0.077)$ & $(0.082)$ \\
\hline \multirow[t]{2}{*}{ VC- backed dummy (?) } & 0.315 & 0.379 & 0.432 & -0.101 & -0.042 & 0.028 \\
\hline & $(0.847)$ & $(0.827)$ & (0.781) & $(0.865)$ & $(0.944)$ & $(0.963)$ \\
\hline \multirow[t]{2}{*}{ Underpricing (?) } & -0.767 & -0.571 & -1.437 & 0.724 & 0.663 & 0.708 \\
\hline & $(0.469)$ & $(0.662)$ & $(0.180)$ & $(0.176)$ & $(0.186)$ & $(0.188)$ \\
\hline \multirow[t]{2}{*}{$\ln$ (Assets) (?) } & -0.084 & -0.086 & -0.116 & 0.162 & 0.324 & 0.134 \\
\hline & $(0.897)$ & (0.899) & $(0.854)$ & $(0.811)$ & $(0.656)$ & $(0.844)$ \\
\hline \multirow[t]{2}{*}{$\operatorname{Ln}($ CEO age) (+) } & $9.721^{*}$ & $9.347^{*}$ & $9.736^{*}$ & $5.002^{* * *}$ & $5.371^{* * *}$ & $4.785^{* * *}$ \\
\hline & $(0.076)$ & $(0.085)$ & $(0.068)$ & $(0.006)$ & $(0.006)$ & $(0.007)$ \\
\hline \multirow[t]{2}{*}{$\operatorname{Ln}(1+$ CEO tenure) (?) } & -1.355 & -1.331 & -0.511 & $-1.542^{* * *}$ & $-1.665^{* * *}$ & $-1.451^{* * *}$ \\
\hline & $(0.167)$ & $(0.177)$ & $(0.418)$ & $(0.007)$ & $(0.006)$ & $(0.010)$ \\
\hline \multirow[t]{2}{*}{ CEO founder dummy $(+)$} & 2.117 & 2.019 & 2.274 & $1.656^{* *}$ & $1.798^{* *}$ & $1.588^{* *}$ \\
\hline & $(0.155)$ & $(0.169)$ & $(0.136)$ & $(0.016)$ & $(0.014)$ & $(0.018)$ \\
\hline \multirow[t]{2}{*}{ TD/TA (+) } & $2.931^{*}$ & $3.100^{*}$ & 2.141 & 0.932 & 1.011 & 0.705 \\
\hline & $(0.082)$ & $(0.094)$ & $(0.137)$ & $(0.221)$ & $(0.212)$ & $(0.274)$ \\
\hline Observations & 42 & 42 & 42 & 110 & 110 & 110 \\
\hline Model chi-square & 14.93 & 15.11 & 14.04 & 25.77 & 26.79 & 24.36 \\
\hline p-value & 0.186 & 0.236 & 0.231 & 0.007 & 0.008 & 0.011 \\
\hline Pseudo $\mathrm{R}^{2}$ & $28.78 \%$ & $29.07 \%$ & $27.32 \%$ & $20.39 \%$ & $21.11 \%$ & $19.40 \%$ \\
\hline
\end{tabular}




\section{Table 8: Sensitivity analysis and robustness test}

We perform a conditional matched-pair logistic regression to predict an IPO firm's likelihood of being named in a prospectus liability case. The dependent variable is one if the firm is the target of an IPO-related securities class action lawsuit and zero otherwise. We re-estimate the conditional logistic regressions, varying the time horizons. Coefficients reported in Model 1 are obtained after discarding lawsuits that occurred more than a year after the IPO. Model 2 contains the 2-year benchmark results. In Model 3, lawsuits that were dismissed or withdrawn are excluded. Model 4 provides the unconditional logistic regression results and model 5 provides the results of unconditional logistic regression using white standard errors. Definitions for all variables are given in Appendix 1. Missing data on certain explanatory variables limit the sample size in some regressions. The predicted signs for each regressor are provided in parentheses besides the variable names. One-tailed test is applied for directional hypotheses. To denote statistical significance, we use *** for the $1 \%$ level, ${ }^{* *}$ for the $5 \%$ level, and * for the $10 \%$ level.

\begin{tabular}{|c|c|c|c|c|c|}
\hline & $\begin{array}{l}\text { Lawsuits } \\
\text { within } 1 \text { year }\end{array}$ & $\begin{array}{l}\text { Lawsuits } \\
\text { within } 2 \text { years }\end{array}$ & Settled cases & $\begin{array}{c}\text { Unconditional } \\
\text { logistic } \\
\text { regression }\end{array}$ & $\begin{array}{l}\text { Unconditional } \\
\text { logistic regression } \\
\text { (White errors) }\end{array}$ \\
\hline & Model 1 & Model 2 & Model 3 & Model 4 & Model 5 \\
\hline \multirow[t]{2}{*}{ Intercept } & & & & $-12.038^{* *}$ & $-12.038^{*}$ \\
\hline & & & & $(0.030)$ & $(0.053)$ \\
\hline \multirow[t]{2}{*}{ Incentives from pre-IPO options (+) } & $17.617^{* *}$ & $22.043^{* *}$ & $27.700^{* *}$ & $8.139^{*}$ & $8.139^{*}$ \\
\hline & $(0.041)$ & $(0.020)$ & $(0.037)$ & $(0.089)$ & $(0.100)$ \\
\hline \multirow[t]{2}{*}{ Incentives from equity ownership (+) } & $2.232^{*}$ & $2.941 * *$ & $2.900^{*}$ & $1.378^{*}$ & $1.378^{*}$ \\
\hline & $(0.087)$ & $(0.045)$ & $(0.091)$ & $(0.098)$ & $(0.100)$ \\
\hline \multirow[t]{2}{*}{$\operatorname{Ln}(1+$ bonus) (?) } & -0.072 & -0.073 & -0.069 & -0.051 & -0.051 \\
\hline & $(0.133)$ & $(0.134)$ & $(0.292)$ & $(0.135)$ & $(0.145)$ \\
\hline \multirow[t]{2}{*}{$\%$ Insiders on board ( + ) } & $2.506^{*}$ & $2.285^{*}$ & 1.548 & 1.484 & 1.484 \\
\hline & $(0.067)$ & $(0.077)$ & $(0.267)$ & $(0.236)$ & $(0.197)$ \\
\hline \multirow[t]{2}{*}{ Underwriter rank (?) } & 0.294 & 0.270 & 0.178 & $0.231^{*}$ & $0.231 *$ \\
\hline & $(0.129)$ & $(0.156)$ & $(0.465)$ & $(0.087)$ & $(0.081)$ \\
\hline \multirow[t]{2}{*}{ VC- backed dummy (?) } & 0.322 & 0.306 & 0.678 & 0.179 & 0.179 \\
\hline & $(0.573)$ & $(0.596)$ & $(0.408)$ & $(0.680)$ & $(0.695)$ \\
\hline \multirow[t]{2}{*}{ Underpricing (?) } & 0.198 & 0.189 & -0.842 & -0.109 & -0.109 \\
\hline & $(0.621)$ & $(0.626)$ & $(0.406)$ & $(0.686)$ & $(0.712)$ \\
\hline \multirow[t]{2}{*}{ Ln(Assets) (?) } & 0.229 & 0.248 & 0.589 & 0.028 & 0.028 \\
\hline & $(0.590)$ & $(0.565)$ & $(0.327)$ & $(0.849)$ & $(0.848)$ \\
\hline \multirow[t]{2}{*}{$\operatorname{Ln}($ CEO age) $(+)$} & $4.174^{* *}$ & $4.578^{* * *}$ & $4.237^{*}$ & $2.486^{* *}$ & $2.486^{* *}$ \\
\hline & $(0.014)$ & $(0.006)$ & $(0.062)$ & $(0.023)$ & $(0.033)$ \\
\hline \multirow[t]{2}{*}{$\ln (1+$ CEO tenure) (?) } & $-1.198^{* *}$ & $-1.091^{* *}$ & $-1.062^{*}$ & $-0.492^{*}$ & $-0.492^{*}$ \\
\hline & $(0.013)$ & $(0.012)$ & $(0.065)$ & $(0.085)$ & $(0.092)$ \\
\hline \multirow[t]{2}{*}{ CEO founder dummy $(+)$} & $1.399^{* *}$ & $1.274^{* *}$ & $1.229^{*}$ & 0.358 & 0.358 \\
\hline & $(0.026)$ & $(0.029)$ & $(0.072)$ & $(0.215)$ & $(0.451)$ \\
\hline \multirow[t]{2}{*}{$\mathrm{TD} / \mathrm{TA}(+)$} & $1.564^{*}$ & $1.415^{*}$ & 0.051 & 0.681 & 0.681 \\
\hline & $(0.055)$ & $(0.068)$ & $(0.486)$ & $(0.122)$ & $(0.104)$ \\
\hline Observations & 128 & 140 & 80 & 157 & 157 \\
\hline Model chi-square & 23.50 & 28.26 & 24.79 & 34.65 & 34.65 \\
\hline p-value & 0.036 & 0.008 & 0.025 & 0.074 & 0.074 \\
\hline Pseudo $\mathrm{R}^{2}$ & $16.20 \%$ & $17.71 \%$ & $25.75 \%$ & $9.02 \%$ & $9.02 \%$ \\
\hline
\end{tabular}


Figure 1: The lawsuit timeline

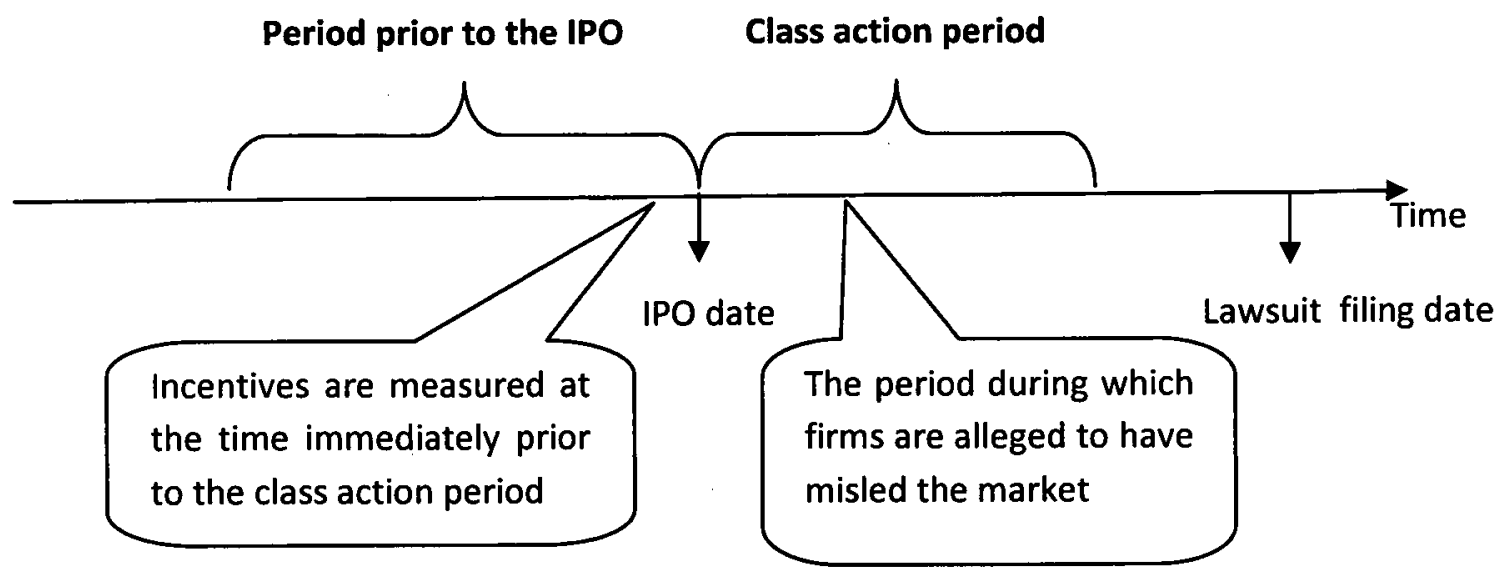

This figure graphically depicts the timeline over which equity incentives are measured. 


\section{Appendix}

Appendix 1: Variable definitions

\begin{tabular}{|c|c|c|}
\hline & Data Sources & Description \\
\hline \multicolumn{3}{|c|}{ Primary dependent variable } \\
\hline Suit & SCAC, SCAA, PACER & $\begin{array}{l}\text { Dummy variable ( }=1 \text { if the firm was sued under Section } 11 \text { of the } \\
1933 \text { Securities Act within three years of its IPO), constructed } \\
\text { using securities class action litigation data from Stanford's } \\
\text { Securities Class Action Clearinghouse (SCAC), the Securities } \\
\text { Class Action Alert (SCAA), and the U.S. Department of Justice } \\
\text { Public Access to Court Electronic Records (PACER) database. }\end{array}$ \\
\hline \multicolumn{3}{|c|}{ Compensation and ownership characteristic } \\
\hline Ln (1+salary) & IPO prospectus & $\begin{array}{l}\text { Natural logarithm of one plus the amount of salary awarded to } \\
\text { the CEO during the last fiscal year prior to the IPO }\end{array}$ \\
\hline Ln (1+bonus) & IPO prospectus & $\begin{array}{l}\text { Natural logarithm of one plus the dollar value of a bonus } \\
\text { awarded to the CEO during the last fiscal year prior to the IPO }\end{array}$ \\
\hline $\begin{array}{l}\text { Incentives from pre-IPO } \\
\text { options }\end{array}$ & IPO prospectus & $\begin{array}{l}\text { Pre-IPO options (vested and unvested) owned by the CEO } \\
\text { deflated by the number of pre-IPO shares outstanding }\end{array}$ \\
\hline $\begin{array}{l}\text { Incentives from pre-IPO } \\
\text { equity ownership }\end{array}$ & IPO prospectus & $\begin{array}{l}\text { Pre-IPO shares owned by the CEO (including the CEO's } \\
\text { immediate family members, and shares in trusts associated with } \\
\text { the CEO) deflated by the number of pre-IPO shares outstanding. }\end{array}$ \\
\hline Ex-ante gain & IPO prospectus & $\begin{array}{l}\text { The hypothetical gain a CEO derives from a } \$ 1 \text { increase in the } \\
\text { offer price (holding the aftermarket price constant) }\end{array}$ \\
\hline IPO option dummy & IPO prospectus & Dummy variable ( $=1$ if the firm grants IPO options, 0 otherwise) \\
\hline \multicolumn{3}{|l|}{ IPO characteristics } \\
\hline Auditor quality dummy & DuCharme et al., 2004 & $\begin{array}{l}\text { Dummy variable ( }=1 \text { if the offering firm's auditor was a Big } \\
4 / 6 / 8 \text { accounting firm, } 0 \text { otherwise) }\end{array}$ \\
\hline Underwriter rank & SDC, Ritter & $\begin{array}{l}\text { Scale for underwriter reputation following Ritter, ranging from } \\
1.1 \text { (worst) to } 9.1 \text { (best) }\end{array}$ \\
\hline $\begin{array}{l}\text { High underwriter rank } \\
\text { dummy }\end{array}$ & SDC, Ritter & Dummy variable ( $=1$ if underwriter rank $>7.1,0$ otherwise) \\
\hline Offer size & SDC & Total offer size in millions of dollars \\
\hline VC- backed dummy & SDC & $\begin{array}{l}\text { Dummy variable ( }=1 \text { if the IPO is venture capital backed, } \\
\text { otherwise) }\end{array}$ \\
\hline Underpricing & CRSP & $\begin{array}{l}\text { Percentage Return from the offer price to the first day closing } \\
\text { price (CRSP) }\end{array}$ \\
\hline \multicolumn{3}{|l|}{ Firm characteristics } \\
\hline OIBD/TA & $\begin{array}{l}\text { IPO prospectus, } \\
\text { Compustat }\end{array}$ & $\begin{array}{l}\text { Operating income before depreciation divided by total assets at } \\
\text { the end of the fiscal year prior to the IPO }\end{array}$ \\
\hline Ln(Assets) & $\begin{array}{l}\text { IPO prospectus, } \\
\text { Compustat }\end{array}$ & Natural Logarithm of the book value of assets \\
\hline $\mathrm{TD} / \mathrm{TA}$ & $\begin{array}{l}\text { IPO prospectus, } \\
\text { Compustat }\end{array}$ & Total debt (long term + short term) scaled by total assets \\
\hline $\operatorname{Ln}(1+$ firm age $)$ & $\begin{array}{l}\text { IPO prospectus, } \\
\text { Compustat }\end{array}$ & $\begin{array}{l}\text { Natural logarithm of one plus the firm's age, where firm age is } \\
\text { defined as the number of years between the firm's founding year } \\
\text { and the year it went public }\end{array}$ \\
\hline $\mathrm{PPE} / \mathrm{TA}$ & $\begin{array}{l}\text { IPO prospectus, } \\
\text { Compustat }\end{array}$ & The proportion of property, plant, and equipment to total assets \\
\hline $\mathrm{R} \& \mathrm{D} / \mathrm{TA}$ & $\begin{array}{l}\text { IPO prospectus, } \\
\text { Compustat }\end{array}$ & $\begin{array}{l}\text { The proportion of research and development spending to total } \\
\text { assets }\end{array}$ \\
\hline
\end{tabular}




\begin{tabular}{|c|c|c|}
\hline \multicolumn{3}{|l|}{ Board and CEO traits } \\
\hline $\operatorname{Ln}($ CEO age $)$ & Ritter, IPO prospectus & Natural logarithm of the CEO's age at the time of the IPO \\
\hline $\operatorname{Ln}(1+\mathrm{CEO}$ tenure $)$ & IPO prospectus & $\begin{array}{l}\text { Natural logarithm of one plus the CEO's tenure defined as the } \\
\text { number of years the CEO has been the CEO of the company }\end{array}$ \\
\hline CEO founder dummy & IPO prospectus & $\begin{array}{l}\text { Dummy variable (= } 1 \text { if it the CEO is the firm's founder found, } 0 \\
\text { otherwise) }\end{array}$ \\
\hline CEO chairman dummy & IPO prospectus & $\begin{array}{l}\text { Dummy variable ( }=1 \text { if the Chairman of the Board is also the } \\
\text { CEO, } 0 \text { otherwise) }\end{array}$ \\
\hline $\begin{array}{l}\text { Ln(number of directors on } \\
\text { the board) }\end{array}$ & IPO prospectus & Natural logarithm of the number of directors on the board \\
\hline$\%$ of Insiders on the board & IPO prospectus & $\begin{array}{l}\text { Percentage of current employees of the firm who serve on the } \\
\text { board }\end{array}$ \\
\hline Exchange dummy & SDC & $\begin{array}{l}\text { Dummy variable ( }=1 \text { if stocks are listed on the NASDAQ , } 0 \\
\text { otherwise) }\end{array}$ \\
\hline
\end{tabular}


Appendix 2: High-Technology Industry Definition

(Source: (http://www.aeanet.org/Publications/Idmk_definition.asp))

"The American Electronics Association (AeA) uses 45 SIC codes to define the high-technology industry. In an effort to produce solid statistics, AeA's definition consists of SIC codes that fall into three broad categories -- high-tech manufacturing, communications services, and software and computer-related services. It does not include broad categories if the high-tech portion does not represent a clear majority. Also, AeA's definition does not include many "related" industries, such as biotechnology, engineering services, and research and testing services.

Other industry groups not covered in AeA's definition of the high-tech industry include wholesale and retail trade of high-tech goods. The biotechnology industry also is not included because current U.S. government statistics do not allow for a clear identification of which portion is "bio" and which is "tech." The matter is further complicated because there is no clear consensus on the definition of the biotechnology industry.

The American Electronics Association (AeA) uses 45 SIC codes that fall into three general groupings -- high-tech manufacturing, communications services, and software and computer-related services -- to identify firms in the high-technology industry ( see below):

\section{HIGH-TECH MANUFACTURING}

\section{Computers and Office Equipment}

3571 Electronic Computers

3572 Computer Storage Devices

3575 Computer Terminals 
3577 Computer Peripherals

3578 Calculating and Accounting Machines

3579 Office Machines

Consumer Electronics

3651 Household Audio and Video Equipment

3652 Phonographic Records and Prerecorded Tapes and Disks

\section{Communications Equipment}

3661 Telephone and Telegraph Apparatus

3663 Radio and TV Broadcast and Communications Equipment

3669 Other Communications Equipment

Electronic Components and Accessories

3671 Electron Tubes

3672 Printed Circuit Boards

3675 Electronic Capacitors

3676 Electronic Resistors

3677 Electronic Coils, Transformers, and Inductors

3678 Electronic Connectors

3679 Other Electronic Components

Semiconductors

3674 Semiconductors and Related Devices

Industrial Electronics

3821 Laboratory Apparatus

3822 Environmental Controls

3823 Process Control Instruments

3824 Fluid Meters and Counting Devices

3825 Instruments to Measure Electricity

3826 Laboratory Analytical Instruments

3829 Other Measuring and Controlling Devices

\section{Photonics}

3827 Optical Instruments and Lenses

3861 Photographic Equipment and Lenses

Defense Electronics

3812 Search and Navigation Systems, Instruments, and Equipment

\section{Electromedical Equipment}

3844 X-Ray Apparatus and Tubes and Related Irradiation Apparatus

3845 Electromedical and Electrotherapeutic Apparatus 


\section{COMMUNICATIONS SERVICES}

4812 Radiotelephone Communications

4813 Telephone Communications

4822 Telegraph and Other Message Communications

4841 Cable and Other Pay Television Services

4899 Other Communications Services

\section{SOFTWARE AND COMPUTER-RELATED SERVICES}

\section{Software Services}

7371 Computer Programming Services

7372 Prepackaged Software

7373 Computer Integrated Systems Design

Data Processing and Information Services

7374 Computer Processing and Data Preparation

7375 Information Retrieval Services

7376 Computer Facilities Management Services

Rental, Maintenance, and Other Computer-Related Services"

7377 Computer Rental and Leasing

7378 Computer Maintenance and Repair

7379 Other Computer-Related Services 